\title{
LA INFIDELIDAD MATRIMONIAL. DELITOS DE ADULTERIO Y AMANCEBAMIENTO EN EL NORTE DE EXTREMADURA DURANTE LA TRANSICIÓN DE LA EDAD MEDIA A LA MODERNA
}

\section{MARITAL INFIDELITY. ADULTERY AND COHABITATION IN THE NORTH OF EXTREMADURA DURING THE TRANSITION FROM MEDIEVAL TIMES TO THE MODERN AGE}

\author{
Tomás SÁENZ DE HARO \\ IES Albalat. Navalmoral de la Mata
}

\begin{abstract}
Resumen
El presente artículo pretende ser un estudio socio-político de los delitos de amancebamiento y adulterio en el territorio de la actual provincia de Cáceres en torno al año 1500. Analizando estos comportamientos como consecuencia de la inserción en la realidad del momento del modelo matrimonial cristiano, monógamo e indisoluble, y su sanción en función de las exigencias de las nuevas mentalidades y del aparato estatal que eclosionan a raíz de la superación de la crisis bajomedieval.
\end{abstract}

Palabras clave: Adulterio, Amancebamiento, Extremadura, Siglos XV y XVI.

\begin{abstract}
This article is aimed at studying the socio-political crimes dealing with cohabitation and adultery in the area of the current region of Cáceres around the year 1500. This behavior will be analysed as a consequence of the introduction of the Christian Marriage in that period, monogamous and indissoluble, and its sanction regarding the exigences of the new ways of thinking and the the State, which arise due to the overcoming of the Late Middle Age crisis.

Key words: Adultery, cohabitation, Extremadura, $15^{\text {th }}$ and $16^{\text {th }}$ centuries.
\end{abstract}




\section{1.- INTRODUCCIÓN, FUENTES DOCUMENTALES Y ESTADO DE LA CUESTIÓN}

Utilizamos la documentación referida a la actual provincia de Cáceres del Registro General del Sello del Archivo General de Simancas, el Registro de Ejecutorias de la Real Chancillería de Valladolid y, en mucha menor medida, el Archivo Histórico Provincial de Cáceres. De estas fuentes, hemos extraído información de diez pleitos por adulterio y tres por amancebamiento. Los escenarios más habituales son las ciudades realengas de Plasencia y Trujillo. Cuatro en Plasencia: en 1493, Francisco Fernández de Sepúlveda, criado del alcaide de la fortaleza, solicita el perdón por haber matado a su mujer adúltera; en 1502, Francisco de Alcántara es acusado de solicitador de adulterio por la mora Fátima Alejurait; cuatro años más tarde, Juan de Pinas denuncia a su mujer Catalina Santillana y su amante Cristóbal de Clavijo, criado del corregidor Juan Núñez de Anguta; y, en 1515, el corregidor licenciado del Espinar actúa contra Mesina de Ribera, supuesta manceba del guardián de San Francisco $^{1}$. Otros tres en Trujillo, que abordan las relaciones de la judía doña Vellida con el alguacil del corregidor Gonzalo de Herrera o Llerena en 1484, las actuaciones de Juan de Cervera contra el adulterio de su mujer Juana García con Rodrigo de Calvarrasa en 1488 y el asesinato de María de las Casas, mujer de Gonzalo Pizarro, y su amante Álvaro Calderón en $1509^{2}$. Dos tienen lugar en la villa de Jaraíz de la Vera, término y jurisdicción de la ciudad de Plasencia; en 1494, cuando se juzga el adulterio cometido por Fernando de Caravagal con la mujer de Gonzalo Muñoz, y en 1519 al denunciar el alcalde Alonso Esteban las relaciones de su mujer, Carolina Gonzalo, con el escribano Pedro Íñiguez 3 . Otros dos los localizamos en villas de la Orden de Alcántara; en Gata Martín Sánchez acusa a su esposa Isabel González y su presunto amante Pedro González en 1492 y, en Torre de don Miguel, Lorenzo de Cieza es denunciado por amancebamiento con Isabel de Villegas ${ }^{4}$. Otro en la Puebla de

\footnotetext{
${ }^{1}$ Real Chancillería de Valladolid (en adelante RCV). Registro de ejecutorias, caja 169, 6; 208, 14 y 303, 13. Archivo General de Simancas (en adelante AGS). Registro General del Sello (en adelante RGS), leg. 149310, 204.

${ }^{2}$ AGS. RGS, leg. 148403, 139; 148405, 54; 148806, 35 y 36; 148809, 55 y 70. Consejo Real de Castilla (en adelante CRC), leg. 590, 6. BEINART, H.: Trujillo. A jewish community in Extremadura on the eve of the expulsion from Spain, Jerusalem, 1980: doc. 11, 19, 20, 22, 47, 49, 60, 68, 69 y 71.

${ }^{3}$ RCV. Registro de ejecutorias caja 335, 63. AGS. RGS, leg. 149405, 115. El concejo jaraiceño cuenta con un juez y dos alcaldes y, desde los Reyes Católicos, con su propio escribano. SÁNCHEZ LÓPEZ, M.: "El concejo de Plasencia en el XVI: instituciones, usos y costumbres según las ordenanzas municipales", XL Coloquios Históricos de Extremadura, Trujillo, 2012, pp. 563 y ss.

${ }^{4} \mathrm{RCV}$. Registro de ejecutorias, caja 47, 20 y 282, 16. Rentas del sacristán y el clavero y bienes de la encomienda mayor de dicha orden se sitúan en Torre de don Miguel, que pertenecería al partido de Gata según el encabezamiento realizado por Felipe II. Ambas se encuentran dentro de la Encomienda de Villasbuenas. FERNÁNDEZ NIEVA, J.: "La Orden de Alcántara en la Extremadura moderna", Campo abierto: Revista de educación, 1, 1982, pp. 146, 175 y s. MONTAÑA CONCHINA, J. L. DE LA: "La red comendataria alcantarina en el
} 
Guadalupe, jurisdicción de dicho monasterio jerónimo, donde María García, la mujer de Blasco de Vegil, es acusada por su marido de tener relaciones con el tendero Francisco Gómez . Y el último está protagonizado por Lorenzo Domínguez, vecino de San Martín de Trevejo -villa de la encomienda hospitalaria de Trevejo-, que denuncia el adulterio y la huída de su mujer María Mateos con Blas Herrazón y Bartolomé, hijo de la Trevejana ${ }^{6}$.

Estas fuentes documentales tienen sus limitaciones. El archivo de Cáceres tan solo nos proporciona alguna información indirecta y los documentos de Simancas son resoluciones solicitadas por una de las partes dentro de procesos presentados ante el Consejo Real, instancia última de justicia. Más interesantes resultan las cartas ejecutorias de la Real Chancillería; aún así solo ilustran seis de los pleitos estudiados $\mathrm{y}$, prácticamente, ninguno de ellos está completo, pues son solo solicitudes, apelaciones que dan una visión parcial del proceso. En general, se trata de instancias judiciales de apelación a las que solo llegan delitos que, como los que estudiamos, se consideran de especial gravedad. Al reducirse nuestras fuentes únicamente a pleitos judiciales es dificil valorar el control social informal que ejercerían la familia y la vecindad, la infrajusticia o acuerdos al margen de los tribunales.

El estudio de este tema justo en torno al año 1500 viene determinado porque es cuando, debido al desarrollo del aparato estatal, comienza a abundar la información documental sobre dichos pleitos. Además, en este momento de transición de la Edad Media a la Moderna aflora una nueva sociedad que, para superar los traumas del siglo XIV, ha experimentado dos importantes transformaciones. Por un lado, una mentalidad más individualista o escéptica frente a un mayor rigorismo contra las infracciones -la campaña de "culpabilización" llevada a cabo por la Iglesia y, en especial, las órdenes mendicantes-; ambas posturas dentro del abandono del racionalismo cristiano que fundamenta los valores morales de siglos anteriores. Por otro lado, unos cambios en la organización socio-política en base a una imposición del poder regio sobre las jurisdicciones nobiliaria, urbana y eclesiástica. El nuevo estado legitima la superioridad de su justicia en pos de un "bien común" que, en parte, se

siglo XV", Revista de Estudios Extremeños, 64, 2008, pp. 731 y ss. Las ordenanzas de Gata se presentan ante el visitador general Frey Antonio de Xérez en 1515. CLEMENTE RAMOS, J.: "Ordenanzas de Gata (1515-1518)", Revista de Estudios Extremeños, 64, 2008, p. 1640.

${ }^{5}$ AGS. RGS, leg. 149805, 141.

${ }^{6}$ RCV. Registro de ejecutorias, caja 401, 106. Desde 1184, la Orden del Hospital posee la encomienda de Trevejo que abarca Villamiel, Villasrrubias y San Martín de Trevejo, a donde se acaba trasladando el centro de la bailía. SÁNCHEZ PÉREZ, A. J. Y MATEOS MARTÍN, L.: "Gobierno municipal y lucha por el poder (San Martín de Trevejo a finales del siglo XVI)". Hernán Cortés y su tiempo, 2. Mérida, 1987, pp. 612 y ss. BERNAL ESTÉVEZ, A.: Poblamiento, transformación y organización social del espacio extremeño (siglos XIII al XV), Mérida, 1998, p. 42. 
ilustra con la persecución de delitos que, como los sexuales, atentan gravamente contra la moral colectiva. Además, el cobro de las multas impuestas a dichas infracciones supone una interesante fuente de ingresos para unos gastos estatales en constante crecimiento - hasta el punto de hablar de un "estado malversador" (Bois, 2001: 163 y ss.)-. Todas estas transformaciones se reflejan en la tramitación de los pleitos que detallamos más adelante.

Con anterioridad, el adulterio y el amancebamiento en la Extremadura tardomedieval han sido tratados de un modo somero dentro de obras de contenido más general como la de Mendoza Garrido sobre la delincuencia en la jurisdicción de la Chancillería de Ciudad Real. De igual modo, algunos casos han formado parte de investigaciones sobre la condición femenina en Extremadura -Rojo Alboreca- y la Corona de Castilla en general -Martín Rodríguez y Álvarez Bezos- o desde la perspectiva de la Historia del Derecho -Aguilar Ros y Collantes-.

\section{MATRIMONIO CRISTIANO MEDIEVAL Y CONCEPTO DE HONRA.}

Entendemos por infidelidad matrimonial la relación sexual de uno de los cónyuges fuera del matrimonio. Como observamos a continuación, ello da lugar a una gran diversidad de situaciones, por tanto, antes conviene entender claramente la definición y trascendencia del matrimonio medieval. La unión matrimonial es la articulación legal de la pareja, núcleo de la familia, principal célula de la sociedad cristiana medieval junto a vinculaciones artificiales como las relaciones feudo-vasalláticas o serviles, la pertenencia a establecimientos religiosos o el asociacionismo en cofradías y gremios (Segura, 2001, 209 y s.). El matrimonio cristiano medieval, monógamo e indisoluble, supone en su época una institución civilizadora, elemento clave de un entramado social cuya continuidad garantiza, al articular las redes de solidaridad familiar a favor de ancianos y, sobre todo, niños, y un sacramento cristiano que encauza el amor y el deseo sexual hacia la procreación y la salvación eterna. Sin embargo, en el matrimonio cristiano medieval se abren importantes grietas, no siendo las menores de ellas su indisolubilidad y la dependencia económica y jurídica de la mujer respecto al marido.

La indisolubilidad del matrimonio abre la puerta a las relaciones extraconyugales una vez que los sentimientos personales cambian y, más aún, si se trata de una unión acordada al margen de los cónyuges sin fundamento sentimental alguno. Desde las "Decretales" de Graciano, la Iglesia defiende el matrimonio por libre consentimiento (Aguilar, 1990: 8 y 193; Martín, 2000: 155 y ss.); sin embargo, 
siguiendo las tradiciones previas germánica y romana, acaba siendo acordado por los grupos familiares. De ahí que el matrimonio sea cada vez menos libre, se celebre a edad más temprana-aumentando los esponsales por palabras de futuro-y se fomente la endogamia dentro de las élites sociales y grupos profesionales; seguramente, menos en las clases inferiores, pues no existen patrimonios socio-económicos relevantes y puede darse con más frecuencia el matrimonio por atracción mutua (Laliena, 2001, 186 y ss.; Navarro, 2014: 70 y ss.; Segura, 2001: 212; Barthhélemy, 2001: 127 y ss.). Un ejemplo en la zona de nuestro estudio son los fueros de Coria-CáceresUsagre que desheredan a la casada sin el consentimiento familiar y establecen la intervención de los parientes en las segundas nupcias de las viudas (Lumbreras, 1974: 65 y s.). De este modo, los esponsales se convierten en uno de los vínculos privados que organizan la sociedad feudal -la denominada "feudalización del matrimonio"-, dando lugar a un deterioro de la condición femenina (Vinyoles, 2006: 188 y ss.; Barthélemy, 2001: 150).

En las sociedades tradicionales, la propia pervivencia del grupo humano impone unos valores morales que, basados en la fuerza física del varón, garantizan, no solo la supervivencia colectiva, sino también la protección de la mujer y la regulación del acceso a ella en pos de asegurar la cohesión y continuidad del conjunto, relegando a la esposa a una dependencia económica y jurídica, más o menos acusada, respecto del marido. Aunque la implantación de la estructura agnaticia resulta más lenta en las comunidades familiares de los reinos hispánicos - no en vano la mayoría de ellos provienen de primitivas sociedades gentilicias matrilineales-, se acaba imponiendo debido a su eficacia para la consolidación de una élite caballeresca, cuya razón de ser es el ejercicio de las armas, actividad exclusivamente masculina. El cristianismo, aun basándose en la igualdad de hombres y mujeres como hijos de Dios y en el recíproco amor entre ellos, es heredero de una tradición hebrea que considera a la esposa la más importante propiedad - pero propiedad al fin al cabo- del marido. Por tanto, a pesar de los ejemplos evangélicos, San Pablo -aunque considera a hombres y mujeres iguales en Cristo- deja bien clara la sumisión de la esposa al marido, denominado como caput mulieris; de este modo, el matrimonio cristiano medieval constituye una relación asimétrica (Martín, 2000, 155 y ss.; 2004, 137 y s.; Segura, 1996, 32 y ss.).

El desequilibrio del contrato matrimonial en perjuicio de la esposa se acentúa durante la Baja Edad Media a causa de la oficialización como saber canónico del aristotelismo - que defiende el carácter incompleto e inferior de la mujer-y la recepción del derecho romano - para quien la mujer es un menor que debe ser tutelado-. A ello se suma la mayor diferencia de edad entre los cónyuges bajomedievales, bien al preferir mujeres jóvenes más moldeables o por la abundante viudedad masculina. 
Aún así, ello no supone dar al marido medieval la impunidad del pater familias romano, pues, en el matrimonio medieval, la entrega de arras y/o dote es garantía del buen trato que el marido debe dispensar a la esposa. Los compromisos matrimoniales altomedievales permiten a la mujer abandonar al marido si este la maltrata, aunque solo sea de palabra; por tanto, la corrección marital debe ser justificada y moderada (Madero, 1992: 591; Vinyoles, 2006: 188 y s.; García Herrero, 2008: 43 y ss.).

Muy relacionado con el matrimonio como garantía del mantenimiento y la continuidad del orden social está el concepto de honra u honor. La honra es la opinión que los demás se hacen de la conducta de un individuo en función de los valores morales del grupo. Tal y como apunta Sánchez Albornoz, a partir del siglo XII el concepto aristocrático de honra, que procede de la dignidad, sangre o nacimiento, se extiende al resto de la sociedad; pero, eso sí, el lenguaje del honor continua describiendo la estructura social y contribuyendo a asignar los recursos para mantener inmutable su estratificación. En consecuencia, aunque generalizado a toda la sociedad, la honra sigue siendo un patrimonio más frecuentemente reclamado por unas élites aristocráticas que la consideran un "capital simbólico", sustento de su predominio social. En un mundo oral como el medieval, la fama pública acarrea importantes consecuencias ante los tribunales, pues permite y respalda el testimonio en los juicios; al contrario, la deshonra y la infamia derivan en exclusión social, devalúan su credibilidad y se extienden hacia familia y vecinos. Este modelo de comportamiento individual se basa en unos roles que, para las mujeres, suponen una conducta sexual casta en pos de producir herederos legítimos para la transmisión de la propiedad y el rango y, para los hombres, la protección y el control de los miembros del grupo familiar -en especial las mujeres- y la venganza de las ofensas recibidas (Solórzano, 2005: 318) ${ }^{7}$. La vigilancia y control maritales se justifican porque el honor, empañado por el miedo a la afrenta, era asunto masculino, público, pero que dependía esencialmente del comportamiento de las mujeres, o sea de lo privado (Barthélemy, 2001: 93 $)^{8}$.

${ }^{7}$ En los fueros pirenaicos, la pérdida de la virginidad, la práctica del sexo durante la viudedad o el adulterio conllevan la ignominia a través de la eliminación de cualquier derecho a la herencia o a la dote; se trata de una exclusión simbólica de la familia y, por ende, del grupo social. LALIENA CORBERA, C.: "Honor, vergüenza y estatus en las familias serviles del Pirineo central en la Edad Media", La familia en la Edad Media. XI Semanas de Estudios Medievales, Nájera, 2001, pp. 198 y ss.

8 ... las mujeres son depositarias de la sangre del linaje, si de sus vidas, mancilladas o castas, intactas o injuriadas, depende la honra de los hombres, es esencialmente la honra de los hombres la que padece las ofensas al linaje, porque las relaciones metafóricas entre sangre y honra se sustentan en una sangre depurada. Las mujeres llevan en el cuerpo la honra de los hombres, pero la relación entre sangre y honra se reconoce en la intimidad del cuerpo masculino. MADERO, M.: "Injurias y mujeres (Castilla y León, siglos XIII y XIV)", Historia de las Mujeres en Occidente, 2: Edad Media, Madrid, 1992, pp. 584 y ss. 
Por tanto, las relaciones extramatrimoniales y los delitos sexuales en general, además de atentar contra las prescripciones religiosas, socavan el orden establecido -pueden subvertir el orden de los linajes- y el "bien común" o conjunto de valores morales asumido por el grupo. La familia, ya sea el extenso linaje nobiliario o la "familia nuclear" popular, es la primera instancia de defensa de la honra, controlando el comportamiento de sus miembros y respondiendo a agresiones y difamaciones exteriores. La segunda es la vecindad; entendida como elemento integrador de los individuos que viven en una misma calle o aledañas -dentro de la ciudad- o en la misma localidad. Se articula participando en actos familiares (matrimonios, funerales...), celebrando juntos festividades y mediante hábitos de solidaridad y protección al prevenir y reprimir la criminalidad, en especial aquellos delitos que, como los sexuales, ponen en entredicho la honra de la comunidad. Por encima de ambas, las élites sociales y la corona utilizan la persecución de los delitos de lujuria para ejercer un control y expresar una voluntad de moralización y mantenimiento del "bien común" y la paz social que forma parte de su discurso social y político (Bazán, 1995: 148 y ss.; Mendoza, 1999: 430 $)^{9}$.

\section{ADULTERIO FEMENINO}

Desde la perspectiva cristiana -a consecuencia de la igualdad entre hombre y mujer como hijos de Dios- se debe sancionar de igual modo las relaciones extramatrimoniales de ambos y así lo establecen los códigos legislativos locales -herederos de una primitiva sociedad gentilicia de carácter matrilineal- ${ }^{10}$. No obstante, siguiendo el pasaje evangélico de Mateo 19, 9, ya el concilio de Elvira (h. 305) aplica diferentes penas a las infidelidades masculina y femenina (García Herrero, 2008: 44). Más aún, conforme se articula la organización socio-política en función de fidelidades privadas de vasallaje o dependencia personal, el delito de adulterio se refiere solo a las relaciones extramatrimoniales de las esposas, mientras que las infidelidades masculinas con mujeres no casadas reciben el nombre de amancebamiento. Solo en algunos casos -según vemos más adelante- se aplica el término de adulterio a

${ }^{9}$... el honor es un capital social que se mantiene y se hace fructificar entre todos, pero cada situación de evaluación vuelve a poner en cuestión tanto el rango como los mismos contornos del grupo solidario. BARTHÉLEMY, D. "La vida privada de las familias aristocráticas de la Francia feudal", Historia de la vida privada 2: De la Europa Feudal al Renacimiento. Madrid, 2001, p. 123.

${ }^{10}$ Las "Decretales" de Graciano establecen la igualdad de los esposos en cuanto a la fidelidad conyugal y los concilios de Valladolid (c. 1322) y Palencia (1388) excomulgan a ambos conyuges infieles. AGUILAR ROS, P.: El adulterio: discurso jurídico y discurso literario en la baja edad media, Granada, 1990, pp. 8, 36 y 185. SÁNCHEZ HERRERO, J.: "Amantes, barraganas, compañeras, concubinas clericales", Clio \& Crimen: Revista del Centro de Historia del Crimen de Durango, 5, 2008, pp. 116 y s. 
relaciones extramatrimoniales de hombres casados especialmente escandalosas. Así, "Las Partidas" definen el adulterio como yerro que ome faze a sabiendas, yaciendo con muger casada o desposada con otro (Part. VII, Tit. 17, ley 1) y persiguen más el adulterio femenino que el amancebamiento masculino con mujeres no casadas salvo en el caso de los clérigos-, pues solo la mujer puede deshonrar al marido y al linaje dándole un heredero ajeno a su sangre -la denominada turbatio sanguinis-, lo que provoca deshonras que rompen la paz social (Aguilar, 1990: 3 y s.; García Herrero, 2008: 62 y s.). Recordemos que hemos reunido diez pleitos de adulterio frente a solo tres de amancebamiento y, en estos años, es el adulterio es el cuarto delito más representado en el Registro General del Sello, tras el homicidio, la agresión y el robo, y es en todos los tribunales, uno de los más imputados a mujeres (Mendoza, 1999: 399 y ss.; 2006: 86 y ss.). En función de todo ello, las esposas adúlteras no solo son traidoras a la fe matrimonial y sacrílegas contra dicho sacramento, sino también injuriadoras contra la honra y fama del marido y su linaje. Algo lógico, pues atenta contra el matrimonio, celula básica de la estructura social y elemento clave en su reproducción, siendo igualmente culpables la adúltera por su infidelidad y el amante por el robo de la mujer, la propiedad más importante del marido.

La reacción más habitual del marido engañado consiste en la restauración de su honra -tanto individual como colectiva-mediante el asesinato vengativo de su mujer y el amante. Durante la Edad Media, la venganza privada es una de las más importantes expresiones de libertad individual y así lo reconocen las más antiguas recopilaciones legales. El "Fuero Juzgo", que nos remite a la legislación visigoda del " $L i$ ber Iudiciorum", permite al marido, padre o hermano castigar a los adúlteros, eximiéndoles de toda pena si los matan y recibiendo el marido y los hijos la dote de la esposa ejecutada (Lib. III, Tit. IV, 1, 3, 12 y 13). En nuestra zona de estudio, el fuero de Plasencia refleja dicha legislación visigótica y los capítulos 64 y 312 del fuero de Cáceres la aceptan para el adulterio flagrante -no solo con la mujer sino también con la parienta- $y$, en caso no flagrante, si se puede probar con el testimonio de hombres buenos, pudiendo la mujer desmentirlo con el voto de doce mujeres casadas (Benavides, 2001: 55; Lumbreras, 1974: 195; Monterde, 2002: 718). Hemos recopilado noticias de varios de estos asesinatos - la esposa del criado del alcaide de Plasencia Francisco Fernández de Sepúlveda y María de las Casas, mujer de Gonzalo Pizarro, y su amante Álvaro de Calderón en Trujillo-e indicios de otro -el vecino de Garciaz Alonso Pizarro mata a su mujer y a Alonso Luengo, pero desconocemos si es a causa de su adulterio ${ }^{11}$-. A pesar de la posibilidad de perdonar a la esposa adúltera -las denominadas "cartas de perdón de cuernos"-y recuperar la mujer junto con su dote

\footnotetext{
${ }^{11}$ AGS. RGS, leg. 148912, 155.
} 
(Córdoba, 1994: 166; Solórzano, 2005: 315), casi siempre se intentan dichos homicidios vengantivos y solo se acude a la justicia pública como último recurso. De esta forma, en la sociedad hispana medieval, la principal causa de uxoricidio es el castigo del adulterio ${ }^{12}$. Costumbres ancestrales y la idea cristiana de familia posibilitan que estos delitos intrafamiliares sean juzgados públicamente. Hacia el año 1000, el "Penitencial de Burchard" considera un pecado imperdonable el homicidio de la esposa y voces como la del franciscano Francesc Eiximenis recuerda a los uxoricidas que responderán ante el juicio divino sobre el gran perill de damnació aquells qui maten les mullers (Vinyoles, 2006: 186; Bazán, 2006: 56 y ss.). Sin embargo, la presión familiar y social resulta demasiado fuerte como para que el marido ignore la situación o se muestre clemente, pues la honra del hombre se mide por su capacidad para proteger y controlar la integridad de su esposa. El grupo familiar y la vecindad, heridos en su honra y amenazados en su legítima continuidad, obstaculizan el perdón del marido a través de injurias y burlas; velando por el orden social, pero generando con frecuencia grandes desgracias (Madero, 1992: 582 y s.) ${ }^{13}$. También el derecho positivo legisla contra el marido consentidor, permitiendo a la justicia pública intervenir sin su denuncia. El "Digesto" sanciona al marido que prostituye a su mujer o no castiga al adúltero sorprendido infraganti, las "Decretales" de Graciano consideran culpable al marido que se acuesta con su mujer sabiendo que es adúltera y "Las Partidas" castigan al marido consentidor (Part. IV, Tit. I, ley 8). Aunque según el "Liber iudiciorum" solo pueden acusar a dicho esposo, hijos legítimos o parientes más próximos (Lib. III, Tit. IV, 13), "Las Partidas" permiten proceder de oficio contra él (Bazán, 1995: 286 y ss.; Collantes, 1996: 205 y ss.) $)^{14}$.

De este modo, la venganza actúa como un instrumento de mantenimiento y restauración del orden al margen del estado; incluso, muchas veces la posibilidad de ejecutarla fuerza arreglos (Mendoza, 1999: 172 y ss.). Pero, en otras ocasiones, da lugar a trágicos enfrentamientos familiares. El 20 de marzo de 1509, acompañados de dos criados - Amarilla y Diego Martínez- y otros veinte jinetes, Gonzalo Pizarro y su cuñado Francisco de las Casas, matan por adúltera a María de las Casas, mujer del primero y hermana del segundo, en su heredad de Tozuelo y al amante de esta,

${ }^{12}$ En Montaillou, Béatrice de Planissoles oculta sus amores adúlteros por miedo a que sus maridos la matasen. LE ROY LADURIE, E.: Montaillou, aldea occitana de 1294 1324, Madrid, 1988, pp. 223 y ss.

${ }^{13}$ La rúbrica 186 del fuero de Cáceres dice qui dixere a otro cornudo, o fududinculo, o gafo, o traidor, o a mugier puta, o zeguladera, o gaffa, peche quereloso V morabetís y el capítulo 499 castiga quemar cuernos salvo en San Juan- ante la puerta de un vecino. MONTERDE GARCÍA, J. C.: "El sentido de la honra en los Fueros de Plasencia y Cáceres", Revista de estudios extremeños, 58, 2002, p. 699.

${ }^{14}$ En los siglos XVI y XVII se castiga al marido consentidor con pena de vergüenza pública y diez años de galeras, la primera, y cien azotes y galeras perpetuas, la segunda. HERAS SANTOS, J. L. DE LAS: La justicia penal de los Austrias en la corona de Castilla, Salamanca, 1991, p. 227. 
Álvaro Calderón hijo de Francisco Calderón, en el camino de Jaraicejo a Trujillo. A continuación, en su huída camino de Portugal, se refugian en la fortaleza de Torrejón, perseguidos por Pedro de Calderón y su hermano Alonso de Loaysa, hijos del difunto Álvaro de Calderón, y su gente con intención de matarlos siguiendo una espiral de venganza ${ }^{15}$.

En consecuencia, la mayoría de los acusados de adulterio huyen para eludir la venganza del marido y son juzgados en ausencia y rebeldía, aunque ello suponga debilitar su posición en el proceso judicial. Así, optan por la huida la mujer de Gonzalo Muñoz, Fernando de Caravagal y el escribano Pedro Íñiguez -quien solo se presenta para ser encarcelado al apelar la sentencia del corregidor Luis de Santillánen Jaraíz de la Vera, la mora Fátima Alexurayt y Cristóbal de Clavijo, criado del corregidor, en Plasencia y Blas Herrazón y Bartolomé, hijo de la Trevejana, en San Martín de Trevejo. Lo que, a su vez, siempre que sea posible, lleva al rápido encarcelamiento de acusados como Juana García, esposa adúltera del trujillano Juan de Cervera, Isabel González, mujer de Martín Sánchez de Gata, y el converso Francisco de Alcántara, solicitador de un adulterio en la aljama placentina.

Evidentemente, a pesar de las presiones sociales, no todos los maridos están dispuestos a ejercer de "médicos de su honra" contra una esposa hacia quien han desarrollado un sentimiento de afecto. Lo intuímos en el caso del jaraiceño Gonzalo Muñoz, quien acepta el retorno a casa de su mujer infiel; de ahí que a su amante Fernando de Caravagal solo se le condene al destierro a más de tres leguas en torno a la villa y el pago de $\operatorname{costas}^{16}$. Otro ejemplo muy expresivo es el acontecido en San Martín de Trevejo, donde Lorenzo Domínguez denuncia al dicho (e a Mari Mateos, su muger) al dicho Blas Herrazón (e Bartolo, fijo de la Trevejana) (tachado) diziendo que...por fuerca e contra su voluntad los dichos Vartolomé, fijo de la Trevejana, e Blas Herrazón dándose favor e aynda el uno al otro e el otro al otro le llevaron a la dicha su muger e ella se le fue e avsentó (por ellos) e se la llevaron al reyno de Portugal donde no parescía por lo qual los suso dichos e cada uno dellos (le avían cometido adulterio o avían $)^{17}$. Una vez oídos los testigos, los alcaldes ordinarios Diego Martín y Francisco López ordenan prender a los acusados que, ante su huída, son juzgados en rebeldía. La condena es bastante laxa -un año de destierro y las costas para Blas Herrazón-, por lo que Lorenzo Domínguez apela ante la

\footnotetext{
${ }^{15}$ AGS. CRC, leg. 590, 6.

${ }^{16}$ Martín Fernández Gomero solicita al Consejo Real levantarle el destierro porque a cabsa de no poder entrar en el dicho lugar de Xarayz se le abía perdido en tres años que ha que pasó lo susodicho e está absente del dicho logar aun diz que más por treinta mil maravedies de su fazienda e que si asi pasase que perdería quanto tenía e reçebiría grande agravio e daño. AGS. RGS, leg. 149405, 115.

${ }^{17}$ RVC. Registro de ejecutorias, caja 401, 106.
} 
chancillería solicitando la pena de muerte y el castigo de su cómplice Bartolomé. Como persiste la ausencia de Blas Herrazón, el 7 de septiembre de 1527, los alcaldes de la chancillería elevan su pena a cien azotes públicos, tres años de destierro y el pago de unas costas tasadas en cuatro mil novecientos cincuenta y siete maravedíes sobre la venta pública de sus bienes. A raíz de la lectura textual, parece tratarse de un secuestro con violación, pero las penas resultan bastante livianas -no castigándose al cómplice Bartolomé- para un delito al que se suele aplicar la pena capital o la enemistad de los parientes de la víctima -es decir, dar vía libre a su venganza(Lumbreras, 1974: 190 y s.) ${ }^{18}$. Además, las menciones al adulterio, la voluntad contraria de la esposa y la participación de Bartolomé, el hijo de la Trevejana, se encuentran interlineadas con posterioridad en el documento original -entre paréntesis en la anterior cita textual-. Por tanto creemos que nos encontramos ante un intento del marido, entendido y comprendido por los alcaldes, pero, eso sí, salvando la honra de ambos; de ahí que dichas interpolaciones transformen el adulterio en una violación con la necesaria participación de un cómplice.

A finales de la Edad Media, el estado busca el monopolio de la justicia en detrimento de las venganzas particulares. Dentro de este lento proceso de afirmación del poder estatal, uno de los primeros y más relevantes hitos es el proyecto de monarquía centralizada del monarca castellano Alfonso X. Así, en "Las Partidas", el marido puede matar al amante si lo sorprende con su esposa, pero esta debe ser entregada a la justicia y, en caso de culpabilidad, es azotada públicamente, encerrada en un convento y pierde la dote (Part. VII, Tit. XVIII, leyes 13 y 15). Un siglo después, el "Ordenamiento de Alcalá" (1348) da un paso atrás al permitir al marido ejecutar a ambos en caso de flagrante delito. Lo mismo dicen las "Leyes de Toro" (1505), pero con la importante salvedad de que, si el marido mata a los adúlteros, no recibe la dote ni los bienes de la mujer y el amante. Esta transformación se produce porque el precio del perdón no va solo a los familiares de la víctima sino también a las arcas reales, de esta manera el estado se aprovecha de los mecanismos económicos de la venganza y de su limitación, y también porque esta ya no resulta efectiva en las ciudades, donde se van disolviendo los vínculos familares sustituidos por un encuadramiento en bandos políticos en los que la venganza es una fuente de desórdenes (Mendoza, 1999: 172 y ss.).

Un ilustrativo ejemplo de interacción entre ambos tipos de justicia es el citado episodio de Torrejón, fortaleza donde -bajo la protección de su pariente García

\footnotetext{
${ }^{18}$ Puede dar lugar a sangrientas venganzas como, en febrero de 1490, la violación de María de Orellana duramente respondida por sus hermanos Martín Alonso y Pedro Alonso de Orellana. FERNÁNDEZ-DAZA ALVEAR, C.: La ciudad de Trujillo y su tierra en la baja Edad Media, Badajoz, 1993, p. 188.
} 
López de Carvajal- Gonzalo Pizarro y Francisco de las Casas se refugian después de asesinar a la adúltera María de las Casas -esposa del primero y hermano del segundo- y a su amante Álvaro Calderón; siendo cercados por los hijos de este y su gente en busca de venganza. En ayuda de los sitiados, acude su también familiar Juan de Sande y Carvajal, padre del señor de Torrejón que, avisado en el camino de Plasencia a Monroy, se presenta en el lugar acompañado de un negro, un mozo de espuelas y un escudero a caballo. Días después, Juan de Sande recibe el socorro de su yerno, Alonso de Sotomayor, y su mujer, Leonor de Saavedra, que, informados por un acemilero, envían a descercar Torrejón a un grupo de vecinos de Monroy ${ }^{19}$. El pesquisidor bachiller Antonio de Mora prende a Juan de Sande, a su yerno Alonso de Sotomayor y a los vecinos de Monroy que vinieron en su ayuda y los lleva a Trujillo donde permanecen presos veinte días, salvo el alcalde y el alguacil de Monroy cuya estancia en la cárcel se prolonga hasta los sesenta días. Lo que les causa un gran perjuicio, sobre todo a los cuarenta labradores de Monroy que no pueden acudir a la siega, valorándose los daños en más de cuarenta mil maravedíes. Además, dicho pesquisidor prende en Cáceres a cinco criados de Juan de Sande y a su deudo el caballero y regidor Macías de Monroy, se los lleva a Trujillo y les impone una pena de ocho o diez mil maravedíes; todo ello sin escuchar testimonios ni tener carta ejecutoria de la sentencia y usurpando los hijos del difunto Álvaro de Calderón, Pedro de Calderón y Alonso de Loaysa, los cargos de alcalde y alguacil de Monroy durante dicho proceso. En total, la actuación de este representante de la justicia regia provoca unas costas y daños que alcanzan los quinientos ducados. El 2 de setiembre de 1509, Juan de Sande solicita al Consejo Real la libre absolución de todos ellos, excusando su comportamiento como la resistencia frente a una facción familiar y reivincando su colaboración con la justicia regia. Asegura que se niega a entregar a sus parientes a sus perseguidores - que atacan las puertas de la fortaleza con piedras y lanzas-para proteger sus vidas y porque no se lo piden oficiales de justicia. Más tarde se presenta allí Gómez Merino, alcalde de la hermandad de Trujillo, pero Juan de Sande recela de él por ser criado de los "Calderones" y, cuando le permite entrar en la fortaleza, los perseguidos ya han huido de nuevo. En cambio, al día siguiente, sí entrega las armas y los caballos que han dejado los fugitivos a Diego Íñiguez, alguacil de Sancho

\footnotetext{
${ }^{19}$ Dichos vecinos de Monroy son Juan García Sastre, Alonso Miguel, Francisco Miguel, Juan Fraile, Diego Hernández, regidor, Juan Mozo de Gonzalo Pérez, Alonso de la Calle, Pedro Estebán, Juan Domínguez, Pedro Rubio, Alonso Mozo de Alonso Pérez, Diego Martín Casillas, Juan de Amor, Lope García, Bartolomé, Juan González, Baltasar Pecelín, Gonzalo Merchán, Gonzalo Núñez, Diego Rodríguez, Juan Franco, Francisco de Casasola, Pedro Domingo, Pedro Franco, Juan Aurón, Juan Mayoral, Tomé Franco, Juan de Martín Juan, Alonso Franco, Juan Marcos, Mateo del Ejido, Macías de Monroy, Juan Cabrero, Alonso Cantero, Alonso Mozo de Alonso Gonzalo, Alonso Sar, Alonso Montero, Gonzalo de Chaves, Fernando de la Plaza y Fernando de Collazos. AGS. CRC, leg. 590, 6.
} 
Martín de Leiva, corregidor de Trujillo, y un alcalde de la hermandad que sí le presentan una carta requisitoria ${ }^{20}$.

Observamos que los representantes regios en Trujillo actúan en persecución de los homicidas, mientras estos cuentan con el respaldo de la sólida posición de sus parientes en instancias de poder locales. Francisco de Carvajal, señor de Torrejón, con su hermano Gutierre de Carvajal, sus hijos García López de Carvajal y Juan de Sande y Carvajal y sus clientes -entre los que se encuentra Diego Pizarro- han dirigido la lucha contra Álvaro de Zuñiga y a favor de los Reyes Católicos. Estos monarcas recompensan a la familia Carvajal con la constitución de mayorazgos en Torrejón y Plasencia que respaldan una fuerte posición en esta ciudad, donde copan los oficios de su regimiento desde 1488. Hasta el punto que, solo dos años antes de estos sucesos, los regidores placentinos que oponen a que Juan de Sande y Carvajal sea nombrado capitán para defender la ciudad ante el duque de Béjar, alegando que es cabecilla de bandos en Cáceres y Trujillo y que temen que forme otro bando en Plasencia (Santos, 1987: 185 y ss.). Su yerno Alonso de Sotomayor es hijo del poderoso Luis de Chaves, auténtico factótum de las elecciones concejiles en Trujillo. Por debajo, también actúan los vínculos feudo-vasalláticos con los principales linajes que controlan el concejo trujillano a finales de la Edad Media. Los asesinados que ejecutan la venganza pertenecen al linaje de los Añasco -incluso, su criado Amarilla también se encuentra bajo esta obediencia-; mientras que los hijos de la víctima son Calderones y Loaysas, integrados en el linaje de los Altamirano (Fernández-Daza, 1993: 166 y ss.). Por tanto, el Consejo Real atiende solo parcialmente dicha apelación para no desautorizar a los representantes regios, pero siendo consciente de que, con la huida de los homicidas, ya se ha frenado una posible espiral de venganzas familiares -el citado Pedro Calderón se retira de la causa-y del diferente peso social de los acusados. El 3 de noviembre de 1509, considera como penas suficientes para Juan de Sande y Alonso de Sotomayor los días que han estado en prisión y las costas y salarios pagados, declarando su libre absolución. Al día siguiente, desestima la apelación de los vecinos de Monroy, confirmando la sentencia del pesquesidor Antonio de Mora con las moderaciones de alzarles el destierro y no condenar en costas a ninguna de las partes. Y, el 15 de noviembre, tampoco acepta las razones de Gómez de Cáceres y Fernando Galeas, pero reduce el destierro hasta la, ya cercana, Navidad y les suspende de sus oficios durante este presente año -es decir, solo mes y medio-, así como les restituye las armas confiscadas, sin condena alguna en $\operatorname{costas}^{21}$.

\footnotetext{
${ }^{20}$ AGS. CRC, leg. 590, 6.

${ }^{21}$ AGS. CRC, leg. 590, 6.
} 
Los maridos que han ejecutado directamente el asesinato vengativo fuera de las circunstancias establecidas por la ley, aún si se demuestra el adulterio, son tratados como cualquier otro asesino. Ya hemos visto que Gonzalo Pizarro y Francisco de las Casas huyen a Portugal para eludir la acción de la justicia. Una vez calmadas las aguas, pueden obtener dos tipos de perdón: el otorgado por los parientes de la víctima hasta el cuarto grado y, solo después, el que ofrece la Corona a cambio de la prestación de servicios -generalmente militares- o de acogerse a los "privilegios de homiciano" (Córdoba, 1994: 170 y s.). Entre los documentos estudiados, solo tenemos un ejemplo al respecto. Francisco González de Sepúlveda, criado del alcaide de la fortaleza de Plasencia, es desterrado por el corregidor Fernando Díaz del Castillo en castigo por el asesinato de su mujer adúltera. Trece meses después, suplica al Consejo Real el levantamiento de la pena. Para ello aporta la retractación del principal testigo de la acusación, Inés Martínez, quien asegura que mintió movida por el odio engendrado en un enfrentamiento anterior ${ }^{22}$; así como el perdón de la madre, hermanos y otros parientes de la víctima porque confiesan ser ella mala muger notoriamente disiendo como ella fuera perpetradora e causadora de su muerte e de cómo hera público ser ella mala muger ${ }^{23}$.

No solo persiste la venganza para castigar el adulterio, sino que muchas veces se recurre a la justicia debido a la incapacidad para actuar directamente, ya sea porque la escasez de recursos no permite renunciar a la dote de la mujer -que se perdería en caso de uxoricidio-, a causa de la huida de la mujer y el amante, o porque estos cuentan con una superioridad social sobre el marido afectado (Mendoza, 1999: 399 y ss.). En esta última situación se hallan varios de los denunciantes en los ejemplos estudiados. El trujillano Juan de Cervera se encuentra con que su mujer adúltera es apoyada por Sancho de Carvajal, provisor del obispado de Plasencia, y su pariente Fernando de Orellana, Vo señor de Orellana desde $1487^{24}$. Blasco de Vegil tampoco puede castigar a su mujer María García, su amante, el tendero Francisco Gómez, y sus solicitadores, Gerónimo de Escalona y la mujer de Alonso de las Casas, protegidos todos ellos por los frailes de Guadalupe, señores del lugar; de ahí que, a través

${ }^{22}$ Porque con gran enojo sydo cabalgando en una mula tomara un chuzo e selo arrojara e le diera conél en las espaldas e que como quiera que la dicha Ynés con aquel enojo fueredes dél la dicha querella. AGS. RGS., leg. 149310, 204.

${ }^{23}$ El el 5 de octubre de 1493 el Consejo Real encarga el caso al corregidor de Plasencia Antonio Cornejo AGS. RGS., leg. 149310, 204. Aunque desconocemos si se trata de un adulterio, Alonso Pizarro, vecino de Garciaz, asesino de su esposa María Paniagua y de Alonso Luengo, en diciembre de 1489, recibe el perdón por el privilegio de Alhama, donde sirve ocho meses a su costa, y por la toma de la villa de Çubia. AGS. RGS., leg. $148912,155$.

${ }^{24}$ Miembro este último del linaje de los Altamirano, presente con frecuencia en los oficios concejiles. FERNÁNDEZ-DAZA ALVEAR, C.: Op. Cit., pp. 166 y ss., 192 y ss. y 422. 
del alcalde real Luis de Polanco, consiga que el Consejo Real remita el proceso al corregidor de Trujillo.

Aunque el estado busca el rentable monopolio de la justicia, en los casos de adulterio, la sentencia condenatoria no hace otra cosa sino canalizar la venganza privada para lavar la honra del marido. El "Fuero Real" -otorgado, entre otras localidades, a Trujillo en 1256- establece que la mujer adúltera y el amante se entreguen al marido para que haga de ellos y sus bienes lo que considere oportuno; pero, si el marido mata a la mujer, debe matar también al adúltero (IV.VII.VI). Eso sí, con el correspondiente escarnio público para que el castigo cumpla su función ejemplarizante y legitimadora del poder regio como superior administrador de justicia ${ }^{25}$. Así, el escribano de Jaraíz, amante de la mujer del alcalde Alonso Esteban, es condenado a ser traýdo por las calles acostumbradas con una soga al pescueço deziendo esta es la justiçia que manda haçer la reyna nuestra señora doña Juana e después sea traýdo a la picota o rollo desta çibdad o donde quiera que fuese prendido $\mathrm{y}$, a continuación, es entregado a dicho alcalde atadas las manos... para que dél faga lo que quisiere o por bien toviere y debe hacerse cargo de las costas -que ascienden a diez mil seiscientos cinco maravedíes ${ }^{26}$. En Plasencia, Juan de Pinas consigue que el amante de su mujer, Cristóbal de Clavijo, le sea entregado con todos sus bienes para que dél faga lo que quisiere o por bien toviere y que haga frente a unas costas de cuatro mil quinientos diez maravedíes ${ }^{27}$. Esta misma pena es el objetivo de Martín Sánchez de Gata al denunciar a su mujer Isabel González y al supuesto amante de esta Pedro González. Y, en San Martín de Trevejo, Lorenzo Domínguez apela la sentencia de los secuestradores y violadores de su mujer por no aver condenado a pena de muerte e pedimiento de bienes al dicho Blas Herrrazón y en la misma pena que los otros sus consortes ${ }^{28}$.

Mendoza Garrido llega a la conclusión de que los juicios por adulterio abundan en entornos urbanos y suelen cometerlos clérigos o gente con una relación de amistad o servicio respecto al marido que, por tanto, tienen más acceso a la esposa; conclusión que, en cierta medida, confirmamos. Por un lado, de los diez procesos por adulterio estudiados, la mitad tienen lugar en ciudades -tres en Plasencia y dos en Trujillo-, por lo que, teniendo en cuenta el predominio de la población rural en la época,

\footnotetext{
${ }^{25}$ Las legislaciones locales establecen para el adulterio las penas de flagelación corporal con vergüenza pública (fueros de Plasencia (100), Béjar (335), Cuenca, Alcañiz, Zorita,), destierro (fuero de Zorita) y penas pecuniarias. AGUILAR ROS, P.: Op. Cit., p. 76.

${ }^{26}$ La cuerda en el pescuezo es un rito servil característico que corresponde al "ritual de la ejecución simbólica”. LALIENA CORBERA, C.: Op. Cit., p. 202.

${ }^{27}$ RCV. Registro de ejecutorias, caja 208, 14.

${ }^{28} \mathrm{RCV}$. Registro de ejecutorias, caja 401, 106.
} 
sí existe cierta tendencia a una mayor práctica del adulterio y/o a una más frecuente denuncia de él en ámbitos urbanos. Aún así, resulta curioso que carezcamos de información acerca de otros dos importantes centros urbanos de la zona: la villa de Cáceres y la ciudad de Coria. Este protagonismo de los entornos urbanos puede explicarse a raíz de que la mayor población de las ciudades permite ocultar mejor el delito y desfigura las relaciones familiares. En las rurales menos pobladas, una familia más extensa y una vecindad más estrecha ofrecen una protección y/o control más férreo frente a las pretensiones del amante adúltero $\mathrm{y}$, sobre todo, se denuncia menos en razón de que los grupos familiares implicados suelen negociar acuerdos y reparaciones al margen de la justicia civil (Córdoba, 1994: 175; Hernández y Testón, 1987: 386; Mendoza, 1999: 526 y ss.; Navarro, 2004: 126 y s.). Por otro lado, aunque no documentamos clérigos entre los amantes adúlteros, estos suelen contar con algún tipo de relación con el marido o se dedican a una actividad que facilita los encuentros con la esposa. En Jaraíz de la Vera, el escribano Pedro Íñiguez coincide con el marido de su amante, el alcalde Alonso Esteban, en el concejo de la villa; en Plasencia, el adulterio de Fátima Alexurayt se organiza dentro de la comunidad mudéjar; en Trujillo, la mujer de Juan de Cervera es seducida por su acemilero Rodrigo de Calvarrasa; y el tendero Francisco Gómez entra en contacto con la mujer de Blasco Vegil en la Puebla de Guadalupe. Sin embargo, como es lógico, lo que resulta esencial es la ausencia del marido. De ahí que estos encuentros furtivos se produzcan en verano -en junio tiene lugar el secuestro y violación de la mujer de Loranzo Domínguez en San Martín de Trevejo y en julio en los casos de Isabel González, mujer de Martín Sánchez en Gata, la mora placentina Fátima Alexurayt y Catalina Santillana, esposa de Juan de Pinas-, no tanto por la calentura estival -ese hermoso verano lleno de recursos que hace nacer el libertinaje a decir del trovador Marcabrú- como aprovechando la ausencia de un marido inmerso en las tareas agrarias ${ }^{29}$.

En Europa, el escenario del adulterio suele ser la casa particular y, rara vez, mesones o posadas; mientras que, en Castilla, se produce la huída a poblaciones alejadas (Córdoba, 1994: 165 y s.). En el norte de Extremadura se dan ambas situaciones. Se emplea la casa particular en el caso de la mora placentina Fatima y el escribano de Jaraíz Pedro Íñiguez, que se encuentra con Carolina Gonzalo en su casa y en otras de diversas partes e logares. Mientras que Martín Sánchez sospecha que su mujer le ha sido infiel en un huerto que es en término de la dicha villa de Gata e asimismo en otros muchos e partes e lugares que al presente no se acordaban y los secuestradores de la mujer de Lorenzo Domínguez la llevan al cercano reino de

\footnotetext{
${ }^{29}$ En Montaillou, el cura Pierre Clergue seduce a su sobrina nieta Grazide aprovechando que su padre se encuentra en la siega. LE ROY LADURIE, E.: Op. Cit., pp. 221 y 229.
} 
Portugal. Estos ejemplos dejan traslucir dos modelos de adulterio: el abandono del hogar con el amante para huir del matrimonio e iniciar una nueva vida o el realizado en busca de un placer esporádico en momentos de ausencia del marido (Mendoza, 2006: 115); como resulta lógico, en ocasiones, el segundo es el paso previo para el primero.

En cuanto a la extracción social de los protagonistas de estos pleitos, según las conclusiones de Córdoba de la Llave, los adúlteros suelen pertenecer a las capas medias y bajas de la sociedad; quizás porque entre los nobles la educación de las mujeres es mayor, el delito no trasciende para evitar el desprestigio social o, gracias al amparo de su posición, ejecutan sus venganzas mediante personal dependiente. En las oligarquías, el marco solidario de la familia, primera barrera protectora frente a la agresión exterior o delito, se amplía al linaje o "familia extensa" y al bando, mientras que, conforme descendemos en la escala social, nos encontramos con la célula familiar o "familia nuclear", cuya capacidad de movilización se restringe, dependiendo del carácter del cabeza de familia para defender su honra (Córdoba, 1994: 160 y ss.; Mendoza, 1999: 526 y ss.; Hernández y Testón, 1987: 387). Nosotros lo corroboramos, pero, además, observamos que los amantes suelen personas con cierta vinculación en instancias más altas y, quizás por ello, más o menos al margen de las estructuras locales de coerción social. Así, nos encontramos con forasteros, relacionados con los representantes del poder regio -el escribano de Jaraíz, el criado del corregidor en Plasencia, el alguacil del corregidor en Trujillo-, o lugareños conectados con las élites eclesiásticas y/o señoriales: Juana García, esposa de Juan de Cervera, y su amante, el acemilero Rodrigo de Calvarrasa, -protegidos por el vicario del obispo de Plasencia y el noble Fernando de Orellana-, María García, mujer de Blasco de Vegil, y su amante, el tendero Francisco Gómez, -respaldados por el monasterio de Guadalupe- o Álvaro de Calderón, amante de la esposa de Gonzalo Pizarro y cliente del linaje trujillano de los Altamirano. Situaciones en gran medida determinadas por el tipo de fuente empleada; en concreto, apelaciones ante el consejo y chancillería de condenas impuestas por una justicia local -ya sea regia o nobiliariamás involucrada con los denunciantes que con los acusados.

Las mujeres adúlteras suelen defenderse, alegando que no están realmente casadas -es decir, por palabras de presente o de futuro seguidas de relaciones sexualeso la invalidez de su matrimonio por parentesco, votos religiosos... (Collantes, 1996: 212 y ss.; Bazán, 1995: 288 y s.). Por tanto, maridos acusadores como el alcalde de Jaraíz Alonso Esteban, el placentino Juan de Pinas, Martín Sánchez de Gata y el vecino de San Martín de Trevejo Lorenzo Domínguez ponen especial énfasis en que se encuentran casados por ley e bendición segun demanda la Santa Madre Yglesia 
de Roma ${ }^{30}$. También resulta habitual responder denunciando, a su vez, el adulterio del marido, pues, según "Las Partidas", si quiere provar que el mismo fizo otro tal yerro, e si lo provare, non debe ser oydo el acusador según derecho de la Santa Iglesia (Part. IV, Tit. 9, ley VII). Esta decisión la toma Isabel González al asegurar que su marido Martín Sánchez de Gata ha cometido adulterio, pero que, al hacerlo con una forastera, no lo pudo acusar. Otra estrategia para desarmar esta acusación es exigir la necesaria independencia de los procesos de la esposa y el amante; así, Cristóbal de Clavijo pretende anular el proceso por haberse llevado de forma conjunta contra él y su amante Catalina Santillana, siendo absuelto en primera instancia sin condena en $\operatorname{costas}^{31}$.

Además, en los pleitos por adulterio juegan un papel capital la familia y la vecindad de los implicados. Algo lógico si tenemos en cuenta que es un delito que pueden denunciarlo parientes y vecinos y para cuya prueba bastan testimonios basados en sospechas y presunciones. Al atentar contra la honra, no solo del marido, sino también de la familia o linaje y del conjunto social, progresivamente se permite que la mujer adúltera pueda ser acusada por un tercero -tal y como establecen las Leyes de Toro-, rompiendo la exclusiva competencia del marido o parientes cercanos que intentan conservar "Las Partidas" en recuerdo del pater familias romano (Collantes, 1996: 205 y ss.). Además, según dicho código, los acusados de adulterio pueden ser castigados si parientes cercanos presentan tres testigos de que han hablado juntos o si la esposa ha ido a casa de un hombre sospechoso contra la voluntad del marido (Part. III, Tit. XIV, ley XII; Part. VII, Tit. 17, ley 11); del mismo modo, las "Leyes de Estilo" permiten probar el adulterio solo por estar encondidos en la casa (Esc Z. III. 11). Asimismo, el fuero de Plasencia permite a las mujeres acusadas de adulterio defenderse con el testimonio de doce vecinas, pero castiga acoger a la mujer perseguida por el marido (Benavides, 2001: 66 y 70). Todo ello sitúa en una débil posición a los amantes y da un gran protagonismo a la vecindad en la defensa de la honra colectiva.

Aunque ya hemos visto cómo familiares y vecinos denuncian los casos de adulterio, controlan el buen comportamiento de la mujer y respaldan y fomentan homicidios vengativos en pos del mantenimiento del buen orden social, también, persiguiendo el mismo objetivo, se oponen a las acusaciones infundadas y a los castigos

\footnotetext{
${ }^{30}$ RCV. Registro de ejecutorias, caja 47, 20; 208, 14; 401, 106. AGS. RGS, leg. 149405, 115.

${ }^{31}$ No obstante, ambos procesos se encuentran interrelacionados pues en caso de huída de uno de ello no se podía ejecutar al otro y la absolución del amante trae consigo la de la mujer. COLLANTES DE TERÁN, M. J.: "El delito de adulterio en el derecho general de Castilla", Anuario de Historia del Derecho Español, 66, 1996, pp. 220 y s.
} 
arbitrarios y desmesurados del marido dentro del grupo. Un interesante ejemplo al respecto es el de Martín Sánchez, vecino de Gata que acusa ante Pedro Mendes, alcalde del maestrazgo de la Orden de Alcántara, y su acompañado Lorenzo Martín a su mujer Isabel González por huir de casa con Pedro González, quienes a dos adulterando e dormían carnalmente en uno o lo quería façer dixo que cometieran adulterio faziendo cópula carnal el uno en el otro; de ahí que solicite le sean entregados dichos adúlteros, para que haga con ellos lo que quisiere, y sus bienes, para abordar las costas. A lo que Isabel González responde que es él quien ha cometido adulterio, mientras que ella con Pedro González ni con otra persona alguna de fecho ni de palabra ni fiziera tales señales que paresciesen forniçio e puesto caso fablase con algunas (personas) lo que alegara non por aquello cometiese ni cometiera forniçio porque si por fablar como fablan unos vezinos con otros syn vileza alguna ${ }^{32}$. Añade que, si huyó a casa de su padre, fue por la mala vida que le dava ynsoportable e ni por esta cabsa alguna para que no la matase syn gelo tener meresçido; e otro porque el dicho Martín Sánchez diz que ponía el puñal a la cabeça para la matar e si fuera fasta que la justiçia se lo quitase e le asegurase. El alcalde mayor alcantarino absuelve a los acusados, restituyéndoles sus buenas famas, debido a las escasas pruebas aportadas por Martín Sánchez, que es condenado en costas. A continuación, se suceden las apelaciones. Fray Antonio de Jérez, corregidor del maestre de Alcántara, ratifica la sentencia al declarar los testigos que Isabel González era muger honrrada e onesta. Martín Sanchez apela a la Real Chancillería recusando al alcalde Pedro Mendes y porquél provara faser aver amonestado a la dicha su muger que non fablase a persona del mundo nin con el dicho Pedro Goncales en casa ninguna e que no estrañe la dicha amonestaçión fablase con el dicho Pedro Gonçalez e con otras personas e demás de fablar conellas cometiera el dicho adulterio e forniçio. Ello nos remite a lo establecido en "Las Partidas" acerca de que si un hombre sospecha que su mujer comete adulterio debe, como medida preventiva, certificar sus temores por escrito y ante testigos, prohibir a su mujer que vea o esté junto al sospechoso en público ni en privado (Part. VII, Tit. XVII, ley 12). Asimismo, para probar su acusación, pide interrogar a María la Ceselra y Teresa Rodríguez, utilizando la tortura si es necesario. Los jueces de la chancillería desestiman la recusación de dichos alcaldes y no aplican el tormento a los testigos; pero sí apresan a Isabel González y fizieron parescer ante sí çiertas mujeres parteras matronas de las quales e de otras mugeres onestas, casadas e honrradas tomaron e resçibieron justo en forma e so

\footnotetext{
${ }^{32}$ Hay que tener en cuenta que, dentro del retrato arquetípico de la mujer adúltera, se hace hincapié en su condición de callejera y parlanchina, mientras que la mujer ideal es prudente en público y apasionada en privado. MADERO, M.: Op. Cit., p. 584. MARTÍN RODRÍGUEZ, J. L.: "Efectos sociales del adulterio femenino", $M u$ jeres, familia y linaje en la Edad Media, Granada, 2004, pp. 166 y s.
} 
cargo dél vieron e averiguaron a la dicha Ysabel Gonçález y concluyen que la dicha Ysabel Gonçález estaba vergen e non avida ni corronpida. A partir de esta prueba de virginidad, la situación de Martín Sánchez resulta bastante insostenible, no solo carecen de fundamento sus argumentos sino que queda puesta en entredicho su hombría al no haber consumado el matrimonio y, por tanto, resultar este nulo. El trauma provocado por su impotencia sexual quizás se encuentre en la base de los celos que le llevan a formular la acusación, pues el excesivo deseo de la mujer suele ser interpretado como un síntoma de la impotencia del marido (Madero, 1992: 584). Por ello, el 11 de agosto de 1492, dicho corregidor ratifica las sentencias anteriores y condena a Martín Sánchez de Gata a pagar a Isabel González dos mil seiscientos cincuenta maravedíes de $\operatorname{costas}^{33}$.

Tal y como observamos en los pleitos estudiados, resulta habitual que los acusados aleguen un fuero o condición personal que les absuelva de su comportarmiento o relaje el castigo. Dentro de la sociedad cristiana medieval una relación especialmente desequilibrada es la establecida con las minorías mudéjar y hebrea. En las comunidades mudéjares peninsulares, los adúlteros son castigados por su propia familia al margen de la justicia civil (Segura, 1996: 140 y s.); por tanto, la conversión al cristianismo resulta una medida eficaz para, en gran medida, eludir las responsabilidades o aligerar los castigos relativos a acciones anteriores al cambio de credo religioso. El moro converso Francisco de Alcántara ${ }^{34}$ es acusado ante el corregidor Rodrigo de Neyra de intermediario o solicitador cuando, según la mora Fátima Alexurayt, siendo ella casada con Mahomad Galibe, moro, veçino de la dicha çibdad, su marido, e durante el matrimonio de entre ellos el dicho Françisco de Alcántara concertó con Abrayn Vinagre, fijo de Mahoma Vinagre, moro, veçino de la dicha cibdad, diziendo que el dicho Françisco tenía formas como de noche metería al dicho Abrayn Vinagre en su casa en dormir carnalmente con ella e teniendo asy el dicho concierto el dicho su marido metió al dicho Abrayn moro en una noche del dicho mes en carnalmente dormirse con ella e le dexó en la dicha su casa e el dicho su marido salió e cerró el çerrojo por de forma e manera que el dicho Abrayn Vinagre durmiese con ella carnalmente por cuya razón cometiose dicho delito. La citada Fatima pide para él la pena del talión -según del derecho islámico- y consigue su ingreso en prisión. Francisco de Alcántara, además de alegar defectos de forma y la ausencia de la acusadora, centra su defensa en que la dicha Fátyma no le podía acusar de dicho delito por no aver caýdo en él porque puesto caso quél oviese fecho el

\footnotetext{
${ }^{33}$ RCV. Registro de ejecutorias, caja 47, 20.

${ }^{34}$ En 1482 el moro Mahomad, hijo de Andalla de Alcántara, compra un solar en el Ejidillo de Trujillo. LÓPEZ ROL, M. L: Archivo Municipal de Trujillo. Catálogo I (1256-1599), Badajoz, 2007, doc. 202.
} 
delito, lo qual negó, sería ya estinto e perdonado por ser él convertido a nuestra fe e avía que por el tal alguna pena mereçiera que no se podía dar ni executar enél, lo otro porque çierto hera que por el bautismo se le perdonan todos los pecados pues que ansy hera que por el bautismo se le remitieron todos los pecados aquel delito fue remitido pues fuese avido como sy entonces oviera meresçido, lo otro porque la dicha Fátyma no fiso verdadera relaçión más con animo danpnando e calunioso a fin dél poner en odio con los cristianos sentara esto e otras muchas cosas. El corregidor, aunque considera probada la acusación, reduce la pena en atención a que era menor de veinticinco años cuando cometió el delito, ya ha cumplido un largo periodo de prisión y, sobre todo, porque al tiempo que delinquió cerca de lo contenido en la dicha acusación hera moro el dicho Francisco de Alcántara e después acahesydo e hera xristiano e convertido a nuestra santa fe católica en cuyo honor e en honor de nuestra religión xristiana segund opinión de doctores toda la pena se le devera remitir prosiguiendo la más común opinión que es justa cabsa e razón de diminuyrle e quitarle mucho por la dicha pena por averse convertido a nuestra santa fe católica. Lo que supone extender el carácter redentor del bautismo a la jurisdicción civil; ventaja que nos lleva a dudar de la sinceridad de su conversión. Por todo ello, le saca de la cárcel y le condena a tres años de destierro y al pago de las costas. Francisco de Alcántara apela repitiendo las consabidas razones y, en especial, centrándose en el carácter malicioso de la denuncia puesto que la dicha Fátima cometió adulterio con el dicho Abrayme Vinagre e dormió conél carnalmente e antes estava casado conél e agora lo estava e fasía vida maridable de casados como marido e muger de lo qual e delo pasado se presente por presunçión de derecho que la dicha Fatyma Alexurayt de su propia, libre e espontánea voluntad dormió con el dicho Abrayme Vinagre e agora estav Fatyma Alexurayt a conél en su casa de tal manera que non avía cabsa nin razón porque aél se le pudiera pedir cosa alguna. Conviene señalar que el matrimonio con el supuesto amante después de la muerte del marido puede constituir una prueba de dicho adulterio. De ahí que la posición de Fátima como acusadora resulte muy débil, pues, aunque se admite que los hechos se produjeron, su situación de mora acusando a un cristiano y el mantenimiento de la relación adúltera con su amante le niegan cualquier credibilidad jurídica; más aún si no asiste cuando la citan y es declarada en rebeldía. En consecuencia, el 21 de noviembre de 1501 se revoca la sentencia del corregidor Francisco de Neyra, no condenando en costas a ninguna de las partes y absolviendo a Francisco de Alcántara -quien obtiene la carta ejecutoria el 30 de abril del siguiente año- ${ }^{35}$.

\footnotetext{
${ }^{35}$ RCV. Registro de ejecutorias, caja 169, 6. Conviene recordar el dispar castigo que establece el fuero de Plasencia para la violación de una mujer mora - solo se paga una multa de cinco maravedíes eludible con el
} 
Algunos acusados intentan trasladar su proceso a la jurisdicción eclesiástica, bien buscando una sanción más laxa ${ }^{36}$, bien para que entren en funcionamiento sus vínculos con determinadas élites de dicho estado -en concreto, el obispado de Plasencia y el monasterio de Santa María de Guadalupe-; sin embargo, la justicia regia, en pleno proceso de afirmación, suele mostrarse muy celosa de su jurisdicción y el fuero diferenciado ya no es un refugio seguro. Juan de Cervera acusa ante la justicia seglar de Trujillo el adulterio de su mujer Juana García con su acemilero Rodrigo de Calvarrasa. Por intercesión del clérigo Alonso González y del noble Fernando de Orellana, la causa es remitida al tribunal eclesiástico de la diócesis de Plasencia, donde la juzgan el provisor Gonzalo Sánchez y su vicario Carvajal, pariente del citado Fernando de Orellana a través de su matrimonio con Sevilla López de Carvajal. Quien tiene capacidad y contactos para mover el proceso hacia la jurisdicción eclesiástica sería Juana García, pues no podría serlo su amante, un simple acemilero. Juan Cervera no acepta y resulta excomulgado y condenado a cuatro mil maravedíes en concepto de costas; por tanto, apela al Consejo Real diciendo quel dicho Fernando de Orellana se entremetió en lo susodicho porque el dicho Rodrigo de Calbarrasa e la dicha Juana Garçía le dieron una criada del dicho Juan Çervera, moça virgen, con la qual durmió carnalmente e la corrompió su virginidad. Ya no solo nos encontramos ante un problema de jurisidicción, sino ante la grave acusación de prostitución de una doncella. Entonces, los días 12 y 13 de junio de 1488 el Consejo Real ordena a Juan Rodríguez de Jaén, alcalde del corregidor de Trujillo Diego López de Ayala, encargarse del pleito y actuar contra el citado Fernando de Orellana, así como exige al provisor del obispado y a su vicario entregarles a Juana García y trasladarle sus diligencias porque lo contrario sería ynpedir la nuestra justicia en perjuiçio de la dicha nuestra jurisdiçión real. El tribunal eclesiástico se resiste a retirarse del pleito puesto que el dicho Juan de Çervera non nos avía fecho razón verdadera por quanto a su procedimiento le fue pedido fisiesede entre la dicha su muger çierto devorcio e le adjudicasede los bienes -un argumento bastante razonable, pues solo el obispo puede anular el matrimonio en caso de adulterio probado-. Sin embargo, como la justicia civil todavía no ha dictado sentencia, el 27 de

\footnotetext{
testimonio de tres vecinos- o cristiana -la sanción se eleva a doscientos maravedíes y es tenido como enemigo por los parientes de la víctima-. BENAVIDES CHECA, J.: El Fuero de Plasencia, Plasencia, 2001, p. 55.

${ }^{36}$ La justicia eclesiástica utilizaba una serie de instrumentos punitivos con el fin de controlar y corregir la conducta de los fieles. Los tribunales eclesiásticos actuaban para conseguir enmendar una transgresión y las penas impuestas perseguían el arrepentimiento del delincuente. El castigo, como había establecido el IV Concilio de Letrán, formaba parte de un "sistema medicinal", en el que no debía llegarse a derramar sangre ni a la pena capital. SOLÓRZANO TELECHEA, J. A.: "Concubinarios, herejes y usurpadores: justicia eclesiástica, comunicación y propaganda en las montañas del obispado de Burgos en el siglo XV", En la España Medieval, 33,2010, p. 241.
} 
septiembre, el Consejo Real ordena a los dichos alcaldes del corregidor y provisor y vicario episcopales que en treinta días le transfieran dicho proceso ${ }^{37}$.

Un caso similar lo observamos en la Puebla de Guadalupe, donde Blasco de Vegil, el marido agraviado, y el alcalde real licenciado Luis de Polanco no pueden ejecutar las penas contra la adúltera María García, su amante, el tendero Francisco Gómez Tamajón, y los solicitadores o tratadores de sus encuentros amorosos, Gerónimo de Escalona, la mujer de Alonso de las Casas y otras personas a cabsa que los frailes del monasterio de Nuestra Señora Santa María de Guadalupe cuyo es el dicho lugar son a los suso dichos muy favorables. De ahí que, el 10 de mayo de 1498, el Consejo Real ordene al corregidor de Trujillo o a sus alcaldes que lleven a cabo dicha ejecución. Desde el último cuarto del siglo XIV, en la Puebla de Guadalupe, frente a la levantisca vieja oligarquía de grupos familiares de terratenientes, burócratas y oficiales concejiles - protagonistas de un levantamiento antiseñorial en 1406-, se configura un grupo de "hombres buenos" que, sobre todo, proceden de la artesanía y el comercio. Ello favorece la desarticulación de la élite local, pues el protagonismo de estos "hombres buenos" no se sustenta tanto en su capacidad económica como por su nexo con la autoridad señorial a través de la asociación a cofradías, hospitales, beaterios, ... y del servicio directo al monasterio. Seguramente, el amante Francisco Gómez Tamajón, tal y como parece indicar su oficio de tendero, formaría parte de restos comerciantes favorecidos por los gestores monásticos. Respecto a los cómplices del adulterio, situados también al cobijo del poder señorial, solo tenemos alguna información sobre Jerónimo Fernández de Escalona, quien en 1496 vende unas casas en el Barrio de Arriba a dicha institución eclesiástica (Domínguez, 2015: 663 y ss. y 1177, 2016: 282 y ss.).

Por último, también emplean las conexiones que, como ya hemos visto, muchos de ellos tienen con los representantes del poder regio. Ello les permite eludir la acción de la justicia a nivel local, pero no ya cuando el pleito llega a instancias superiores. No lo consigue el citado escribano Pedro Íñiguez, en parte porque el marido

${ }^{37}$ AGS. RGS, leg. 148806,35 y 36; 148809, 55 y 70. Los conflictos del concejo trujillano con el obispo de Plasencia sobre rentas y jurisdicción se remontan resultan frecuentes. El 27 de abril y 28 de noviembre de 1499 acerca del modo de cobrar los diezmos, en especial "de las yerbas" -conviene recordar que el arrendamiento de dehesas y pastos es uno de los principales "propios" o fuentes de ingresos concejiles-. El 29 de marzo de 1500, Isabel la Católica envía un par de cédulas al obispo de Plasencia para que su alguacil en Trujillo no se entrometa en la jurisdicción real, no altere el precio de las sepulturas, provea de confesores a la ciudad y se cierren las iglesias durante las noches. Al mes siguiente se suceden las cartas de poder concejiles para el pleito con el obispo de Plasencia sobre los diezmos de las yerbas, sentenciado el 15 de mayo siguiente por la reina y el obispo de Oviedo. Finalmente, el 4 de febrero de 1503, Isabel la Católica conmina al obispo de Plasencia a poner un vicario en Trujillo que atienda los temas de la jurisdicción eclesiástica en la ciudad. LÓPEZ ROL, M. L.: Op. Cit, doc. $285,290,296-303$ у 317. 
agraviado es el alcalde Alonso Esteban, un personaje de cierta relevancia en Jaraíz de la Vera ${ }^{38}$. De igual modo ocurre con la sentencia dictada por el teniente de corregidor de Plasencia Alonso de Mesa y sus regidores Ferrán Suárez y Francisco de Almendros, quienes en primera instancia, exculpan a Cristóbal de Clavijo - criado de un anterior corregidor de la ciudad-; sin embargo, cuando el marido agraviado recurre a la Real Chancillería, es entregado con sus bienes al acusador y condenado en costas.

\section{AMANCEBAMIENTO MASCULINO}

El amancebamiento, o adulterio masculino con una mujer no casada, cuenta con una elevada permisividad social y no se considera adulterio propiamente dicho al no incidir sobre la descendencia legítima y la transmisión del patrimonio económico y la posición social ${ }^{39}$. En una sociedad donde la mayoría de las parejas responden a consideraciones socio-económicas del grupo familiar y los consagrados a la vida religiosa están sujetos al celibato, la pasión y el amor discurren en gran medida por cauces extramatrimoniales. Además, la soledad de muchas mujeres -solteras sin dote, viudas, abandonadas por el marido...- las deja en una situación vulnerable sin el respaldo jurídico y económico del cónyuge ${ }^{40}$. En los estratos inferiores de la sociedad, la imposibilidad de dotar a las hijas deja a estas en una situación especialmente vulnerable, dedicándose muchas de ellas al servicio doméstico y siendo recurrentes víctimas de habladurías e, incluso, de abusos, tal y como hemos visto en el caso de la doncella, criada de Juan de Cervera, entregada a los apetitos carnales del señor de Orellana ${ }^{41}$. Por no entrar en el caso de prostitutas y adúlteras confesas, cuya desconexión de las estructuras protectoras de la familia y la vecindad las convierte en

${ }^{38}$ Años antes, en 1505, el juez licenciado Vergara lo condena por apropiarse y deslindar la tierra de Yedra, entre Jaraíz y Torremenga. GARCÍA OLIVA, M. D.: "Usurpaciones de tierras comunales en el término de Plasencia a fines de la Edad Media, Studia Historica. Historia Medieval, 35, 2017, p. 170.

${ }^{39}$ El zaragozano Luis de Santángel, que era dado mucho a mugeres y putanero mucho de mugeres, es considerado por la Inquisición un buen cristiano. GARCÍA HERRERO, M. C.: Op. Cit., pp. 62 y s.

${ }^{40}$ Sirva de ejemplo como, el 8 de febrero de 1527, una vecina de Cáceres, ya que su marido García Iarmones es ydo e avsentado desta dicha villa e de su tierra muchos días á e no está enlla ni se espera pide permiso al bachiller Pedro Zárate, teniente de corregidor, para poder nombrar procuradores que gestionen su patrimonio y el de sus hijos y los defiendan en pleitos. AHPC. Protocolo notarial, 3914, 1.

${ }^{41}$ De ahí que abunden las obras pías de dotar a doncellas jóvenes sin recursos y que los propios amos suelan encargarse de la dote de sus criadas. VINYOLES VIDAL, T.: "Ajudes a donzelles pobres a maridar", La pobreza y la asistencia a los pobres en la Cataluña medieval, Barcelona, 1980, pp. 362 y ss. NAVARRO GAVILÁN, B.: La sociedad media e inferior en Córdoba durante el siglo XV. Familia y vida cotidiana, Tesis doctoral, Universidad de Córdoba, 2014, pp. 80 y ss. El "Fuero Real" permite que las mujeres mayores de treinta años sin padre puedan casarse sin el consentimiento del hermano para evitar su desclasamiento. SEGURA GRAIÑO, C.: "Las mujeres en la organización familiar", La familia en la Edad Media. XI Semanas de Estudios Medievales, Nájera, 2001, p. 212. 
blanco de acosadores -como doña Vellida ante los requerimientos de Juan Ruiz, según explicamos más adelante-. Estas situaciones abocan a muchas mujeres a buscar la protección masculina como mancebas de casados o clérigos. De este modo, el amancebamiento -además de dar rienda suelta al amor sincero- puede suponer una mejora de la vida de las mancebas, sobre todo si estas son de baja condición y sus amantes nobles o clérigos. Todo ello a costa de sacrificar la honra porque, aunque muchas veces, entre los grupos más desfavorecidos, la honra funciona como una "válvula de escape" que compensa las penurias cotidianas -la denominada "honra del pobre"-, otras personas de baja extracción social tienen un sentido de la honra menos acentuado que las élites ante lo exiguo del patrimonio a transmitir (Testón, 1985: 150).

Desde nuestra perspectiva actual, menos razonable resulta la libido desaforada de algunos nobles como el comendador de la Orden de Alcántara, y fundador de un importante linaje nobiliario, Gutierre de Sotomayor, quien, pese a estar obligado al celibato, cuenta con cuarenta amantes y quince hijos ilegítimos reconocidos en su testamento en 1453 (Rojo, 1987: 63 y ss.) ${ }^{42}$. A la hora de explicar estas situaciones, desde luego que tenemos presente que el poder y la riqueza abren puertas y vencen voluntades, pero creemos que también resulta relevante el sólido cimiento que una extensa red familiar, aun ilegítima, supone para una élite; el crecimiento de la parentela es un deber del cabeza de linaje (Barthélemy, 2001: 80). Así, en zonas como el País Vasco, es un instrumento de los linajes banderizos para ampliar su red de fidelidades agnaticias y asegurar la existencia de herederos (Bazán, 1995: 281 y ss.); algo especialmente importante en una época de elevadísima mortalidad infantil, un $42,5 \%$ entre los niños de sangre real. En consecuencia, la solidaridad familiar nobiliaria solía reconocer a los bastardos y tolerar el amancebamiento.

En general, aunque condenado por la legislación, la sociedad consiente el amancebamiento porque suele dar lugar a relaciones estables, una especie de "pseudomatrimonio" que también contribuye a la construcción y perpetuación del edificio social, no teniendo el efecto disolvente del adulterio sobre la institución matrimonial y la transmisión del patrimonio y la posición porque, según dicen "Las Partidas", los fijos que nasçieren dellas fueren más çiertos (Martín, 2000: 174 y ss.). Esta permisividad social queda reflejada en las distintas compilaciones legales que establecen los derechos de las mancebas o barraganas y de sus hijos a la herencia del padre,

\footnotetext{
${ }^{42}$ Durante la centuria anterior, el caso de la familia oligárquica de los Clergue. LE ROY LADURIE, E.: Op. Cit., pp. 214 y ss.
} 
diferenciándolos de las situaciones derivadas de una esporádica infidelidad ${ }^{43}$. Así, en "Las Partidas" se establece que los "bordes" o hijos ilegítimos deben ser expulsados, pero fijan un paralelismo entre los hijos de barragana y de mujer legítima, siendo aquellos fácilmente legitimados, pues, aunque prohíben la barragana al casado, al soltero le permiten tener una siempre que no sea mujer de vil condición (Part. IV, Tit. 13, ley 1). Realmente, el amancebamiento preocupa más por suponer un medio de promoción social que por su inmoralidad. Ya en la zona de nuestro estudio, el fuero de Plasencia concede a la barragana la mitad de los bienes gananciales (Benavides, 2001: 138 y ss. y 199) y especialmente ilustrativo resulta, en 1446, el testamento de Hernando Alonso de Orellana, quien -como es habitual- se preocupa por sus mancebas e hijos bastardos y, en cambio, -lo que no es tan frecuente- no menciona a su mujer legítima (Rojo, 1987: 59). La justicia regia no castiga el amancebamiento hasta las cortes de Soria (1380) y Briviesca (1387), cuando se obliga a las mancebas de clérigos y casados a llevar signos distintivos e infamantes -en concreto, la venda colorada que an de atraer alderedor de la cabeça por manera que sean conoçidas entre las otras mujeres onestas- y se les impone, sobre otras penas que determinen las justicias locales, el pago de un marco de plata -dos mil doscientos diez maravedíes-. Disposiciones que se repiten en las cortes de Toledo (1480), ya bajo los Reyes Católicos ${ }^{44}$. Estamos ante la afirmación de un aparato estatal que, mediante la persecución judicial de los delitos sexuales, busca su legitimación -al identificar sus objetivos con un bien y una moral colectivos-, y su financiación a través del cobro de las multas. Sin embargo, a la hora de aplicarlas, prima más el interés recaudatorio que la corrección de dichas conductas que, como ya hemos visto, cuentan con alto grado de aceptación social. Así, las palabras de Mendoza Garrido acerca de que no parece que las justicias locales pongan mucho empeño en acabar con el amancebamiento de los clérigos, antes bien, parecen ejecutar una simple

\footnotetext{
${ }^{43}$ El fuero de Zamora trata la barraganía como un contrato de amistad y compañía y el de Ávila le garantiza una serie de rentas como si fuera una sierva; en los de Plasencia y Zamora, la barragana recibe la mitad de los bienes gananciales; y en los de Cuenca, Alcalá de Henares, Brihuega, Fuentes de la Alcarria, Alfambra, Ayala, "Fuero Real" y "Fuero Viejo", los hijos ilegítimos heredan con los legítimos. El título 175 del "Libro de los Fueros de Castilla" establece que los hidalgos puedan dejar quinientos sueldos a sus hijos de barragana; según "Las Partidas", reciben una sexta parte y, según el fuero de Soria, un cuarto. En las cortes de León (1208), la barragana cuenta con los mismos derechos que la esposa, accediendo los hijos de ambas uniones a los bienes de los padres. Incluso, las "Leyes de Toro" (1505) permiten conceder a los hijos ilegítimos un quinto de lo testado. AGUILAR ROS, P.: Op. Cit., p. 90, 99, 137 y ss. y 185. MARTÍN RODRÍGUEZ, J. L.: Op. Cit., pp. 155 y ss.

${ }^{44}$ AGS. RGS, leg. 149002, 164. En 1387, Juan I establece que el hombre entregue un quinto de sus bienes -hasta diez mil maravedíes- a la familia de su manceba para que se case o entre en un convento; asimismo, en 1400, según una ley de Enrique III, el hombre amancebado con mujer casada pierde la mitad de sus bienes. MARTÍN RODRÍGUEZ, J. L.: Op. Cit., pp. 155 y ss.
} 
recaudación periódica a costa de las mujeres (Mendoza, 2006: 120) serían extensibles a todo tipo de amancebamiento.

En consecuencia, los pleitos estudiados responden a la iniciativa de poderes públicos -el corregidor de Plasencia y el alcalde de Torre de don Miguel-. Siguiendo un mandato de la reina doña Juana, el corregidor placentino licenciado del Espinar realiza pesquisas sobre el amancebamiento de casados y clérigos y apresa a Mesira de Ribera que confiesa ser la manceba pública del guardián de San Francisco. Termina condenándola al pago de un marco de plata, un año de destierro y a las costas correspondientes. Mesira y su procurador apelan ante la Real Chancillería alegando que sy alguna confesyón avía hecho del dicho delito avía sydo con justos temores que la avían puesto e siendo ella ynoçente de todo lo contra ella pedido e sentençiado, seguramente porque se ha empleado el tormento o la amenaza de él en su interrogatorio. Finalmente, el 30 de agosto de 1515, los alcaldes de la chancillería aceptan sus pruebas y la absuelven, no condenando en costas a ninguna de las partes. En Torre de don Miguel, es el alcalde ordinario Juan Martínez quien procesa a Lorenzo de Cieza por su relación con Isabel de Villegas, apresándolo y condenándolo en primera instancia a que sea sacado de la cárçel pública desta villa e ençima de un asno e con una soga a la garganta e atadas las manos e asy sea traýdo por las calles principales desta villa diçiendo en pregón público diçiendo la cabsa porque se a de fazer la justiçia por pregón público e dicha desta manera esta es la justiçia que manda fazer el rey nuestro señor. No obstante, Lorenzo de Cieza apela y, el 19 de febrero de 1513, es absuelto por los alcaldes de la chancillería y le son devueltos sus bienes sin condena en $\operatorname{costas}^{45}$.

Caso aparte es el de la judía viuda doña Vellida, quien a dormido e fecho adulterio... muchas veses con Gonzalo de Herrera o Llerena, alguacil del corregidor de Trujillo y, más tarde, con Juan Ruiz. Al no tratarse de una mujer casada, sería tecnicamente un amancebamiento, pero, eso sí, con dos importantes agravantes que motivan a sus contemporáneos para calificarlo como adulterio. Uno es su condición de viuda que le presupone castidad, pues lo contrario sería atentar contra la memoria del marido fallecido a quien debe fidelidad post mortem. Los fueros de Villavicencio, Palenzuela, Pozuelo de Campos, Zamora, Salamanca y Ledesma, el "Fuero Juzgo" (III; 1, 2, 8 y 9) establecen que la viuda no pueda volver a contraer matrimonio hasta un año después de la muerte del marido (Aguilar, 1990: 78). El capítulo 68 del fuero de Cáceres castiga el fornicio de la viuda: vida que tálamo fiziere, peche VI morabetís, III a los alcaldes et III al conceio (Lumbreras, 1974: 196). Por tanto, salvo las

\footnotetext{
${ }^{45}$ RCV. Registro de ejecutorias, caja 303, 13 y 401, 106.
} 
clases nobiliarias - debido a la presión social del linaje-, son escasas las viudas que contraen un segundo matrimonio -en Córdoba un 5\% de las mujeres frente a un 10\% de hombres ${ }^{4}{ }^{46}$. El otro, y quizás más importante, es el contacto sexual de cristiano con infiel que, en consecuencia, carece de una honra basada en unos valores en gran parte cristianos ${ }^{47}$; aún así, según el "Fuero Juzgo" (XII, 2, 6), los judíos no pueden hacer adulterio con su parienta y, si se casan, deben seguir las costumbres cristianas (Aguilar, 1990: 109).

La aljama judía de Trujillo puede actuar contra doña Vellida a través del BethDin, -tribunal dirigido por un Dayan o Rabbí-, pero no si esta, como es el caso, es una viuda rica respaldada por su amante Gonzalo de Herrera o de Llerena, alguacil del corregidor Sancho del Águila. Así lo expresa la propia aljama que quiere proçeder contra la dicha doña Vellida, dis que non osan por temor e miedo que han del dicho alguasil, que no rebuelva algúnd remedio o escándalo en la dicha çibdad. En 1484, el 6 de marzo, los Reyes Católicos ordenan a Alonso Contreras, vecino de Valladolid, que investigue el caso y, el 11 de mayo, tras haber remitido su pesquisa e inquisición al Consejo Real, los monarcas comisionan al corregidor de Trujillo para que lo juzgue. La repetición de esta comisión el 6 de septiembre evidencia la falta de colaboración de Sancho del Águila para actuar contra su alguacil. Sin embargo, la destitución de dicho corregidor y la ayuda del recaudador de impuestos de origen hebreo Gonzalo Pérez Jarada permiten la detención de doña Vellida, imponiéndole la multa de seis mil maravedíes. Una vez perdida la protección del citado alguacil y el crédito social tras dicha condena, doña Vellida es un blanco fácil para acosadores como Juan Ruiz, a cuyos violentos e insistentes requerimientos acaba accediendo. Entonces, en 1490, el nuevo corregidor, Diego Arias de Anaya, la trata con extrema dureza y comienza a dar tormento a dicha doña Vellida, por cuya cabsa dis que dixo quel dicho Juan Ruys se echava con ella, e que estando ansy, que dende a dos días, syn la más oyr, la fesistes cavalgar un asno e dar de açotes por esa dicha çibdad, e que la desterrastes perpetuamente e le condenastes en la mitad de sus bienes para la nuestra cámara. Más aún, aunque en febrero de 1491 la corona le levanta el embargo de sus bienes y le permite volver durante quince días para organizar su casa y cobrar deudas, una vez en Trujillo es ahorcada por el corregidor y se le confisca el

\footnotetext{
${ }^{46}$ Muchos testamentos exigen que la viuda no vuelva a casarse; incluso, la acusación de adulterio -aceptable hasta seis meses después del óbito del marido-podía utilizarse para despojar a la viuda de la dote. COLLANTES DE TERÁN, M. J.: Op. Cit., pp. 207 y s. NAVARRO GAVILÁN, B.: Op. Cit., p. 64 y ss.

${ }^{47}$ El capítulo 386 del fuero de Cáceres establece que nadie responda, al igual que los alcaldes, que sorprendiera a judio con cristiana, si esto pudiera probarse con el testimonio de dos cristianos y un judio o con el de dos judios y un cristiano... Toda cristiana hallada con judio o la condujeran, estando constituido el concejo, apliquen la misma justicia tanto para uno como para otro. MONTERDE GARCÍA, J. C.: Op. Cit., p. 704. LUMBRERAS VALIENTE, P. Los fueros municipales de Cáceres. Su derecho público, Cáceres, 1974, p. 196.
} 
resto de sus bienes. En marzo de 1492, sus hijos Yucé, Salomón y Meyr piden que el corregidor devuelva dichas propiedades y el judío Zetri Arrovas haga lo propio con los maravedíes que se le han dado a guardar ${ }^{48}$.

La vida privada de doña Vellida no se adapta a los cánones morales judeo-cristianos -sirva de ejemplo que hasta 1478 su hijo Meyr ha jurado por la vida del rey no volver a entrar a su casa-. No obstante, la rapiña observada sobre sus propiedades -que le obligan a jugarse la vida volviendo a Trujillo para protegerlas- nos hablan de, además de consideraciones de moral pública, un interés económico mucho menos confesable sobre su patrimonio por parte de las autoridades concejiles y hebreas en consonancia con las tensiones existentes dentro de la aljama trujillana ${ }^{49}$. Este mismo interés económico también lo apreciamos en las penas pecuniarias impuestas a Mesira de Ribera y Lorenzo de Cieza. Además, todas estas sanciones tienen un componente de agravio público - azotes, paseos en asno, destierro- con una finalidad ejemplarizante para corregir conductas y legitimar la justicia regia.

\section{CONCLUSIONES}

Para algunos autores como Gacto Fernández, el duro castigo del adulterio femenino respecto al amancebamiento masculino en la sociedad medieval es el más claro exponente de la inferior consideración de la mujer ${ }^{50}$. Nosotros, en virtud de los pleitos estudiados, no estamos de acuerdo. En las líneas anteriores queda reflejada de forma palmaria la dependencia jurídica y económica de la esposa medieval respecto de su marido; así como los peligros a los que se enfrentan las mujeres cuando carecen de la protección masculina -recordemos a la criada de Juan de Cervera-. No obstante, la extrema dureza de las penas contra el adulterio femenino deriva del carácter disolvente de dicho delito para el mantenimiento y la reproducción de las estructuras sociales. Y, dentro de cada tipo delictivo -infidelidad femenina o adulterio e infidelidad masculina o amancebamiento-, la persecución y el castigo de estos delitos sexuales se activa de igual modo para el hombre y la mujer. Así, el escribano de Jaraíz

\footnotetext{
${ }^{48}$ En 1489-90, Gonzalo Pérez Jarada declara que Gonzalo de Llerena y doña Vellida son sus enemigos por ser como son graçia e honra de Sancho del Águila e porque le quieren mal porque le quitaron el corregimiento de Trugillo... una ve después quez vino a su casa un esecutor de la corte de sus Altezas a los prender por algunas cosas que dellos se dixeron e este puso en su casa del dicho mi parte, porque era çriado del licenciado de Yllescas, y después que los prendió lleno de costas a la doña Vellida seys mil maravedís. BEINART, H.: Op. Cit., p. 347 y doc. 19, 20, 22, 47, 49, 60, 68, 69 y 71.

${ }^{49}$ Acerca del pago de los castellanos de oro para la Guerra de Granada. FERNÁNDEZ-DAZA ALVEAR, C.: Op. Cit., pp. 195 y s. BEINART, H.: Op. Cit., pp. 25 y ss. y doc. 11.

${ }^{50}$ Citado por ROJO Y ALBORECA, P.: Op. Cit., p. 60.
} 
Pedro Íñiguez y el placentino Cristóbal de Clavijo son entregados a los maridos de sus amantes para que ejecuten su venganza y Gonzalo Pizarro y Francisco de las Casas asesinan tanto a María de las Casas - esposa adúltera del primero- como a Álvaro de Calderón -el amante de esta-; también la sanción por amancebamiento es la misma para Mesira de Ribera en Plasencia y Lorenzo de Cieza en Torre de Don Miguel. Por lo que la diferencia esencial entre la distinta aplicación del castigo a un mismo delito parece residir, más que en el sexo del acusado, en su ubicación y conexiones dentro del entramado social. Bajo este prisma se entiende la dureza empleada contra doña Vellida; su situación de viuda amancebada le distancia de sus correligionarios de la aljama trujillana y su condición de judía la margina dentro de la sociedad cristiana. Así como el apoyo que encuentran algunas adúlteras y sus amantes entre nobles y eclesiásticos -señor de Orellana, vicario y provisor episcopales, monjes de Guadalupe...- en su intento por eludir la acción de una justicia regia cuyo avance resulta imparable ante las jurisdicciones particulares.

Según Chiffloeau, el adulterio es una válvula de escape para los problemas afectivo-sexuales en matrimonios acordados con gran diferencia de edad entre los cónyuges; en una línea similar, Rojo y Alboreca y Testón Núñez consideran abundantes las relaciones extraconyugales a consecuencia de lo habitual de los matrimonios de conveniencia (Testón, 1985: 146 y s.; Rojo, 1987: 46 y ss.). Aunque el adulterio es el cauce por donde discurre la pasión más allá de los estrechos límites del matrimonio, Córdoba de la Llave relativiza su frecuencia en los momentos tardomedievales y para Mendoza Garrido la abundancia de estos pleitos no manifiesta la fragilidad del matrimonio como institución (Córdoba, 1994: 166, 179 y s.; Mendoza, 1999: 400 y ss.). Nosotros compartimos esta conclusión, más aún si tenemos en cuenta que, en la España bajomedieval, encontramos unas tasas de nupciabilidad $-90 \%$ en Úbeda, $80 \%$ en Murcia y Córdoba- más elevadas que en otros lugares de Europa -entre $60 \%$ y $70 \%$ en Toscana- (Navarro, 2004: 61). En el ocaso de la Edad Media, aflora una mentalidad más individualista y escéptica que convive con una fuerte tendencia de moralización y restricción sexual en la doctrina matrimonial dentro de un mundo más obsesionado por el pecado y su castigo. Todo ello provoca una sociedad moderna con una dosis de cinismo mayor de lo habitual en cualquier grupo humano. Cinismo derivado del necesario juego entre la moral del grupo y las exigencias éticas en pos de la supervivencia individual y de la cohesión del grupo familiar y/o vecinal. Como ya hemos visto, dichas realidades son consecuencia de la superación de la crisis del siglo XIV mediante la legitimación y financiación del aparato estatal como instancia suprema de administración de justicia frente a la venganza privada y a las jurisdicciones locales y eclesiásticas. Se avecinan buenos tiempos para un estado que 
demuestra sobradamente su eficacia durante los siguientes siglos. Aunque una moderada corrupción es la grasa que permite el funcionamiento de la maquinaria administrativa, nadie discute la legitimidad de un estado cuyos valores morales que todos asumen y cuya estabilidad está garantizada por una cínica utilización del perdón para amparar comportamientos que, aun contrarios a estos valores, adaptan a las circunstancias particulares. Pues, aunque aumentan los pleitos por delitos sexuales -sobre todo a raíz de la expansión de la justicia estatal-, se suavizan los castigos al adaptarlos a la realidad del entramado familiar y vecinal, se intenta erradicar las venganzas personales previas, y se constata una elevada permisividad social del amancebamiento. Aún así, en la Castilla bajomedieval las penas impuestas a estas infracciones -entrega al marido para su muerte, pena de muerte y/o destierro con pérdida de bienes- resultan más duras que en el resto de Europa, donde predominan sanciones económicas (Córdoba, 1994: 166, 179 y s.; Mendoza, 1999: 400 y ss.; Navarro, 2014: 61). La razón residiría en la empresa reconquistadora, culmen de las ambiciones caballerescas, que aumenta el sentimiento de honor en la península respecto al resto del continente (Monterde, 2002: 686 y s.).

\section{BIBLIOGRAFÍA}

AGUILAR ROS, P. (1990): El adulterio: discurso jurídico y discurso literario en la baja edad media, Granada.

ÁLVAREZ BEZOS, M. S. (2015): Violencia contra las mujeres en la Castilla del final de la Edad Media, Valladolid.

BARTHÉLEMY, D. (2001): "La vida privada de las familias aristocráticas de la Francia feudal", Historia de la vida privada 2: De la Europa Feudal al Renacimiento. Madrid, pp. 57-171.

BAZÁN DÍAZ, I. (1995): Delincuencia y criminalidad en el País Vasco en la transición de la Edad Media a la Moderna, Vitoria.

(2006): "Mujeres, delincuencia y justicia penal en la Europa medieval. Una aproximación interpretativa", Mujer, marginación y violencia entre la Edad Media y los tiempos modernos, Córdoba, pp. 29-74.

BEINART, H. (1980): Trujillo. A jewish community in Extremadura on the eve of the expulsion from Spain, Jerusalem.

BENAVIDES CHECA, J. (2001): El Fuero de Plasencia, Plasencia.

BERNAL ESTÉVEZ, A. (1998): Poblamiento, transformación y organización social del espacio extremeño (siglos XIII al XV), Mérida. 
BOIS, G. (2001): La gran depresión medieval: siglos XIV-XV. El precedente de una crisis sistémica, Valencia.

CLEMENTE RAMOS, J. (2008): “Ordenanzas de Gata (1515-1518)”, Revista de Estudios Extremeños, LXIV, pp. 1639-1671.

COLLANTES DE TERÁN, M. J. (1996): “El delito de adulterio en el derecho general de Castilla", Anuario de Historia del Derecho Español, 66, pp. 201-228.

CÓRDOBA DE LA LLAVE, R. (1994): “Adulterio, sexo y violencia en la Castilla medieval”, Espacio, Tiempo y Forma, 7, pp. 153-189.

(2006): “Mujer, marginación y violencia entre la Edad Media y los tiempos modernos", $M u$ jer, marginación y violencia entre la Edad Media y los tiempos modernos, Córdoba, pp. 7-27.

DOMÍNGUEZ DE LA CONCHA, A. (2015): Oligarquía rural y régimen señorial en Extremadura en la Baja Edad Media: el ejemplo de Guadalupe. Tesis Doctoral. UNED.

(2016): “Ascenso y declive de la élite rural de la Puebla de Guadalupe (Cáceres) durante los siglos XIV y XV”, Studia Historica. Historia Medieval, 34, pp. 271-295.

FERNÁNDEZ-DAZA ALVEAR, C. (1993): La ciudad de Trujillo y su tierra en la baja Edad Media, Badajoz.

FERNÁNDEZ NIEVA, J. (1982): "La Orden de Alcántara en la Extremadura moderna”, Campo abierto: Revista de educación, 1, pp. 139-188.

GARCÍA HERRERO, M. C. (2008): "La marital corrección: un tipo de violencia aceptado en la Baja Edad Media", Clio \& Crimen: Revista del Centro de Historia del Crimen de Durango, 5, pp. 39-71.

GARCÍA OLIVA, M. D. (2017): "Usurpaciones de tierras comunales en el término de Plasencia a fines de la Edad Media, Studia Historica. Historia Medieval, 35, pp. 157-178.

HERAS SANTOS, J. L. DE LAS. (1991): La justicia penal de los Austrias en la corona de Castilla, Salamanca.

LALIENA CORBERA, C. (2001): "Honor, vergüenza y estatus en las familias serviles del Pirineo central en la Edad Media", La familia en la Edad Media. XI Semanas de Estudios Medievales, Nájera, pp. 179-208.

LE ROY LADURIE, E. (1988): Montaillou, aldea occitana de 1294 1324, Madrid.

LÓPEZ ROL, M. L. (2007): Archivo Municipal de Trujillo. Catálogo I (1256-1599), Badajoz. LUMBRERAS VALIENTE, P. (1974): Los fueros municipales de Cáceres. Su derecho público, Cáceres.

MADERO, M. (1992): “Injurias y mujeres (Castilla y León, siglos XIII y XIV)”, Historia de las Mujeres en Occidente, 2: Edad Media, Madrid, pp. 581-592.

MARTÍN RODRÍGUEZ, J. L. (2000): "El proceso de institucionalización del modelo matrimonial cristiano", La familia en la Edad Media. XI Semana de Estudios Medievales, 
Nájera, pp. 151-177. (2004): "Efectos sociales del adulterio femenino”, Mujeres, familia y linaje en la Edad Media, Granada, pp. 137-190.

MENDOZA GARRIDO, J. M. (1999): Delincuencia y represión en la Castilla bajomedieval, Granada.

(2006): "Sobre la delincuencia femenina en Castilla a fines de la Edad Media", Mujer, marginación y violencia entre la Edad Media y los tiempos modernos, Córdoba, pp. 75-126. MONTAÑA CONCHINA, J. L. DE LA. (2008): "La red comendataria alcantarina en el siglo XV”, Revista de Estudios Extremeños, 64, pp. 717-759.

MONTERDE GARCÍA, J. C. (2002): "El sentido de la honra en los Fueros de Plasencia y Cáceres", Revista de estudios extremeños, 58, pp. 685-722.

NAVARRO GAVILÁN, B. (2014): La sociedad media e inferior en Córdoba durante el siglo XV. Familia y vida cotidiana, Tesis doctoral, Universidad de Córdoba. .

ROJO Y ALBORECA, P. (1987): La mujer extremeña en la Baja Edad Media: amor y muerte, Cáceres.

SÁNCHEZ HERRERO, J. (2008): “Amantes, barraganas, compañeras, concubinas clericales”, Clio \& Crimen: Revista del Centro de Historia del Crimen de Durango, 5, p. 106137.

SÁNCHEZ LÓPEZ, M. (2012): "El concejo de Plasencia en el XVI: instituciones, usos y costumbres según las ordenanzas municipales”, XL Coloquios Históricos de Extremadura, Trujillo, p. 563-580.

SÁNCHEZ PÉREZ, A. J. Y MATEOS MARTÍN, L. (1987): “Gobierno municipal y lucha por el poder (San Martín de Trevejo a finales del siglo XVI)”. Hernán Cortés y su tiempo, 2. Mérida, pp. 612-620.

SANTOS CANALEJO, E. C. de. (1987): "Linajes y señoríos de la Alta Extremadura: Monroy y Carvajal”. Hernán Cortés y su tiempo, 1. Mérida, pp. 183-191.

SEGURA GRAIÑO, C. (1996): "Tiempo de hombres. Tiempo de mujeres", Entre la marginación y el desarrollo: mujeres y hombres en la historia. Homenaje a $M^{a}$. Carmen García Nieto. Madrid, pp. 27-42.

(1996): "Las mujeres en la España medieval”, Historia de las mujeres en España, Madrid, pp. 115-245. (2001): “Las mujeres en la organización familiar”, La familia en la Edad Media. XI Semanas de Estudios Medievales, Nájera, pp. 209-219.

SOLÓRZANO TELECHEA, J. A. (2005): “Justicia y ejercicio del poder: la infamia y los delitos de lujuria en la cultura legal de la Castilla medieval”, Cuadernos de historia del derecho, 12, pp. 313-353.

(2010): “Concubinarios, herejes y usurpadores: justicia eclesiástica, comunicación y propaganda en las montañas del obispado de Burgos en el siglo XV", En la España Medieval, 33, pp. 233-257.

TESTÓN NÚÑEZ, I. (1985): Amor, sexo y matrimonio en Extremadura, Badajoz. 
TESTÓN NÚÑEZ, I. y HERNÁNDEZ BERMEJO, M. A. (1987): “Tiempo de Inqusición (La represión social en la Extremadura del siglo XVI)". Hernán Cortés y su tiempo, 1. Mérida, pp. 376-379.

VINYOLES VIDAL, T. (1980): “Ajudes a donzelles pobres a maridar”, La pobreza y la asistencia a los pobres en la Cataluña medieval, Barcelona, pp. 362-371.

(2006): "No puede aceptarse crueldad tan grande". Percepción de la violencia de género en la sociedad feudal”, Mujer, marginación y violencia entre la Edad Media y los tiempos modernos, Córdoba, pp. 185-200.

Tomás SÁENZ DE HARO http://orcid.org/0000-0002-0053-522X tsaenzd01@educarex.es 